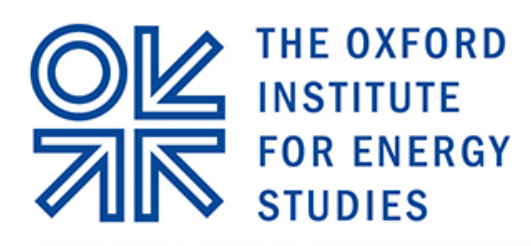

A RECOGNIZED INDEPENDENT CENTRE OF THE UNIVERSITY OF OXFORD

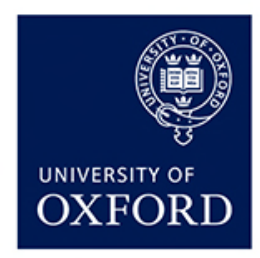

September 2016

\title{
Advancing Renewable Energy in Resource-Rich Economies of the MENA
}

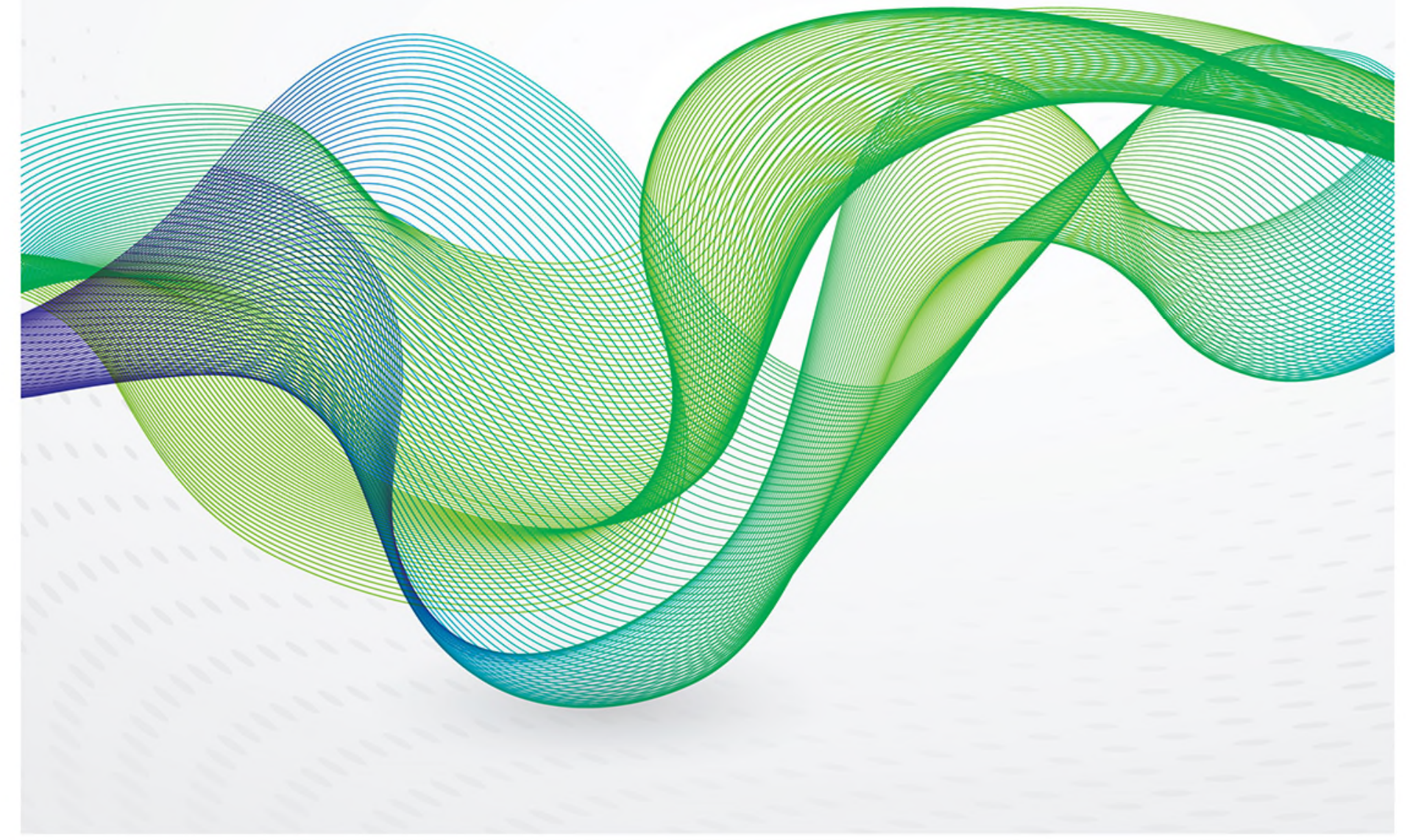


The contents of this paper are the authors' sole responsibility. They do not necessarily represent the views of the Oxford Institute for Energy Studies or any of its members.

Copyright @ 2016

Oxford Institute for Energy Studies

(Registered Charity, No. 286084)

This publication may be reproduced in part for educational or non-profit purposes without special permission from the copyright holder, provided acknowledgment of the source is made. No use of this publication may be made for resale or for any other commercial purpose whatsoever without prior permission in writing from the Oxford Institute for Energy Studies.

ISBN 978-1-78467-069-6 

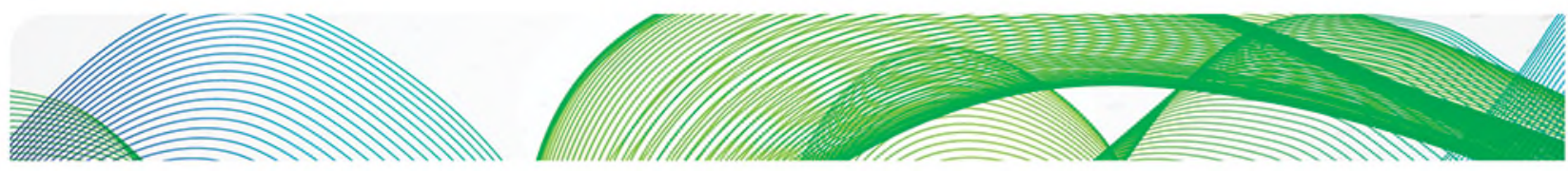

\section{OVI}

\section{Acknowledgements}

The authors would like to thank Osamah Al-Sayegh, Anton Eberhard, Adnan Shihab-Eldin, Malcolm Keay, David Robinson and Jonathan Walters for their comments on previous drafts of this paper. Many thanks to Justin Jacobs and Kate Teasdale for their help with copyediting and production. OIES is grateful to the Kuwait Foundation for the Advancement of Sciences (KFAS) which facilitated this research. 

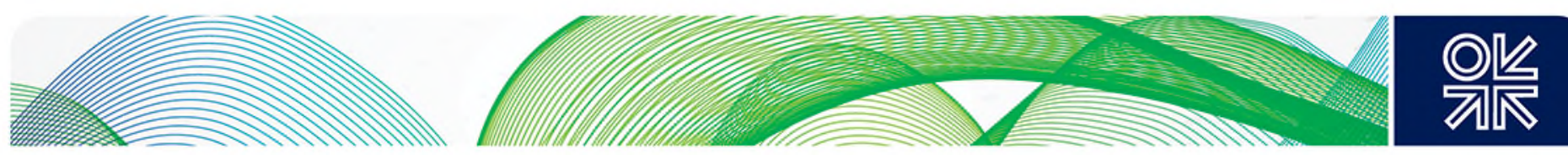

\begin{abstract}
As much of the world pushes ahead with the deployment of renewable energy, resource-rich MENA economies are lagging behind. For the region to catch up, new policies are required to remove barriers of entry to the industry and create investment incentives. This paper contends that while the main obstacles to deployment of renewables are grid infrastructure inadequacy, insufficient institutional capacity, and risks and uncertainties, the investment incentives lie on a policy instrument spectrum with two polar solutions: (i) the incentive is provided entirely through the market (removing all forms of fossil fuel subsidies and internalising the cost of externalities); or (ii) the incentive is provided through a full government subsidy programme (in addition to the existing fossil fuel subsidies). However, there is a trade-off between the two dimensions of the fiscal burden and political acceptance across the policy instrument spectrum, which implies that the two polar solutions themselves are not easily and fully implementable in these countries. Therefore, we propose a combinatorial approach in which the incentive for renewables deployment is provided through a partial renewable subsidy program and partial fossil fuel price reform in a way that balances the fiscal pressure on the government against political acceptability. Additionally, the paper argues that the fact resource-rich countries are behind advanced economies in electricity sector reform gives them a last-mover advantage in the sense that they can tap into years of international experience to avoid design mistakes and create a sustainable solution that is compatible with renewables deployment and their own context.
\end{abstract}

Keywords: renewables deployment, MENA, energy sector reform, resource-rich, investment JEL classification: Q40, Q48, Q28 

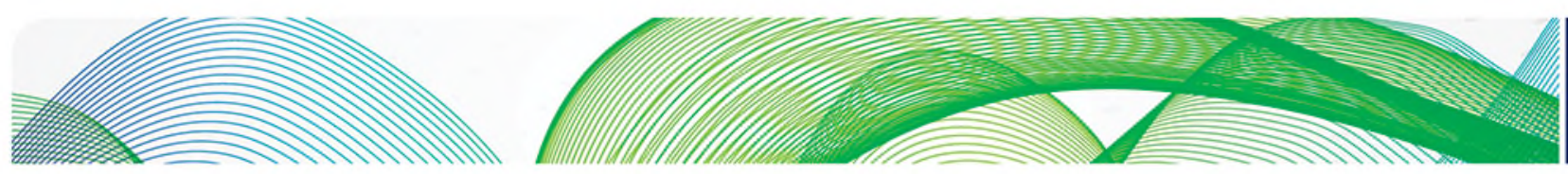
O는

\section{Contents}

Acknowledgements 3

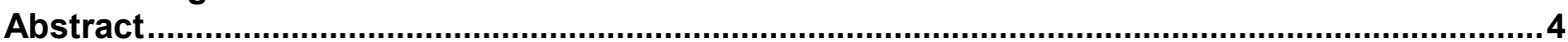

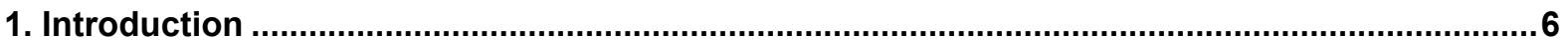

2. The current status of renewables in resource-rich MENA countries .......................................8

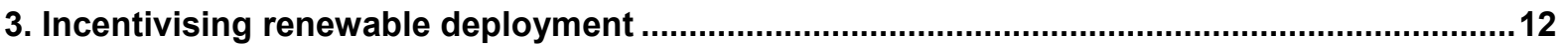

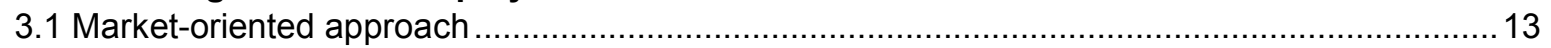

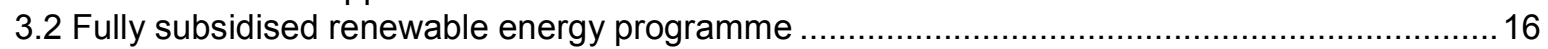

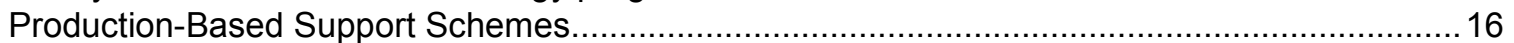

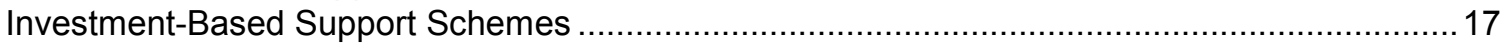

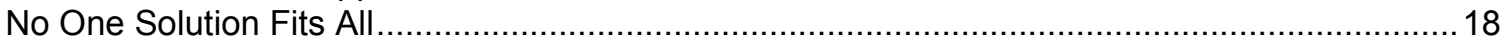

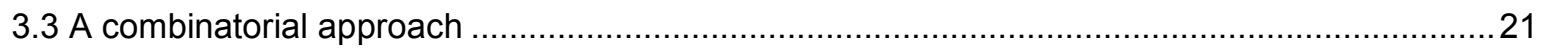

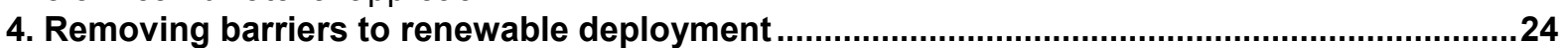

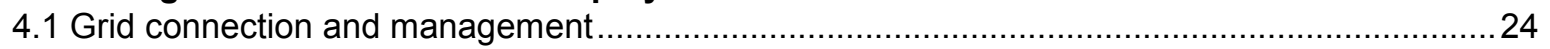

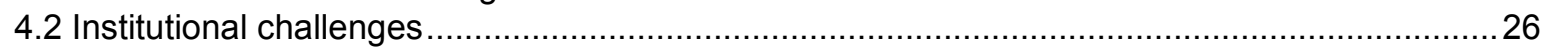

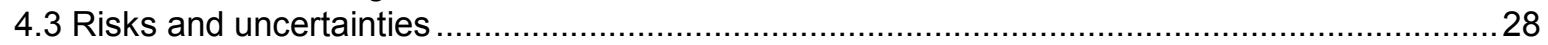

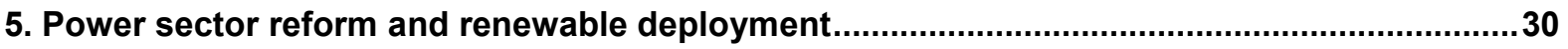

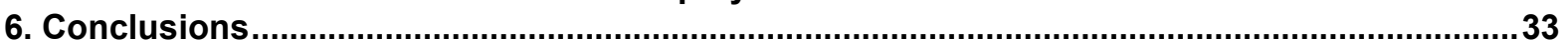

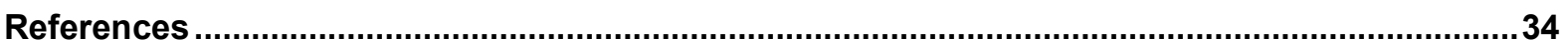

\section{Tables}

Table 2.1: MENA Domestic Targets on Renewable Energy ................................................... 9

Table 2.2: Renewables (ex-Hydro) Electric Installed Capacity in MENA Countries, ........................10

Table 3.1: Renewables LCOE versus retail tariffs in resource rich MENA countries ........................15

Table 3.2: Evaluation of suitability of support schemes for resource rich countries of MEA ..............19

Table 3.3: Renewable support policy schemes currently adopted in the MENA .............................20

Table 4.1: Grid Access for Renewables in Selected MENA Countries, 2015.................................25

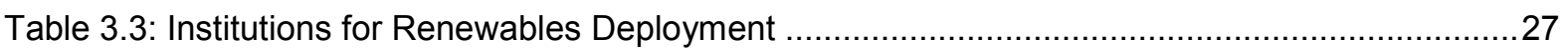

\section{Figures}

Figure 2.1: Renewables as a share of net electricity generation (\%) by country income classification .8 Figure 2.2: An assessment of resource dependency in resource-rich MENA Countries....................11

Figure 3.1: A stylised model of renewable enhancement .................................................... 12

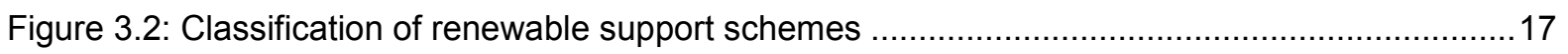

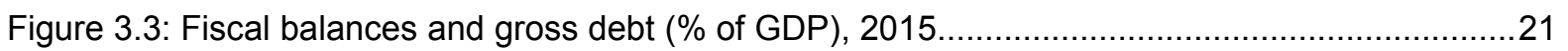

Figure 3.4: Policy instrument spectrum for incentivising renewable investment .............................22

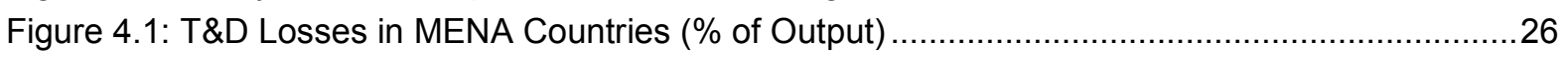

Figure 5.1: Models of electricity market structure and the range of feasible renewable support

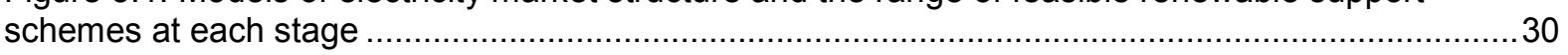

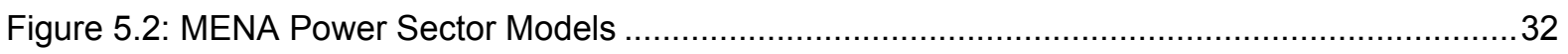



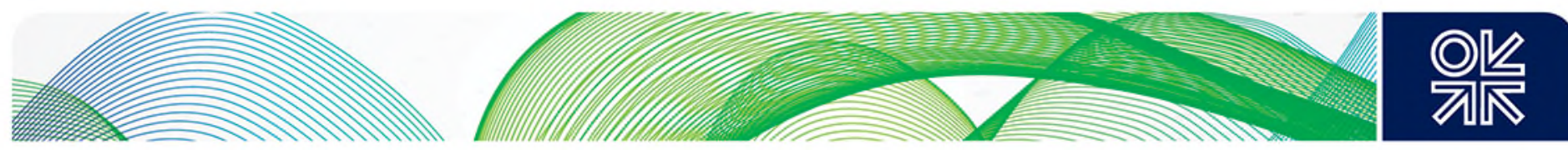

\section{Introduction}

There are many reasons why major oil and gas producing economies of the Middle East and North Africa (MENA) need to keep pace with the rest of the world and invest in renewable energy. Among these are rapidly growing domestic energy demand, growing uncertainty over long-term demand for hydrocarbon resources, the ensuing need for economic diversification, the importance of maintaining fiscal stability and tightening constraints from global environmental policies. Rising electricity demand driven by economic growth, high rates of urbanisation, expanding populations, and low electricity prices have meant that increasing amounts of liquid fuels (crude oil, fuel oil and even diesel) and natural gas (imported in a number of countries) are diverted to the power sector, often at prices below international levels (Lilliestam and Patt, 2015).

In the last two decades, state-owned utilities in the region have responded to soaring electricity demand by building the cheapest and quickest options for new generation, usually open cycle gas turbines or oil-fired boiler plants. These technologies' low energy conversion efficiencies are compensated by cheap, almost unlimited fuel reserves (Dyllick-Brenzinger and Finger, 2013). Shortfalls in revenue collection have contributed to insufficient cost recovery by utilities, impeding capacity investments. The funding for investments frequently falls back on national budgets, pushing up government expenditure, which is in turn reliant on resource revenues. ${ }^{1}$ Thus, resource-rich MENA countries face a triad of challenges: rising electricity demand, thinning reserve margins and generation investments increasingly subject to the budget constraint from low oil prices (Dyllick-Brenzinger and Finger, 2013).

At the same time, resource-rich MENA economies have great potential for renewable energies, owing to high levels of irradiation throughout, and wind potential in some. Many countries in the region also have fewer limitations on the use of land for construction of wind and solar farms. Furthermore, their locations are often close to the regions' main energy markets. Collectively, these conditions create a unique opportunity for MENA countries to exploit their renewable resources to their full potential to serve rising domestic demand, whilst also harmonizing with the changing global energy landscape in which renewables are fast becoming mainstream. ${ }^{2}$ By increasing the share of renewables in electricity, MENA countries can free crude oil and natural gas for export markets. Renewables can help reduce their climate footprint ${ }^{3}$, as per capita emissions are amongst the world's highest. Also, renewables can contribute to economic diversification by establishing new industries and developing the local value chain. There is also a strong belief that renewables can create high-quality jobs that would be desired by the local population. ${ }^{4}$

Despite the start of large-scale projects and the huge potential for renewables, to date the share of renewable energy only accounts for 1 per cent of total primary energy and 3.5 per cent of electricity generation across the entire MENA region (this differs across the resource-rich and resource-poor countries of the region). Moreover, more than 90 per cent of renewables consists of hydroelectricity, whilst the share of non-hydro resources barely exceeds 1 per cent of total electricity generation in the region (IISD, 2014).

\footnotetext{
${ }^{1}$ MENA countries including Saudi Arabia and Kuwait, launched ambitious renewable research and development programmes in the 1970s and 1980s following the two oil price shocks (spikes); however, these were later abandoned following a fall in oil prices and fiscal pressures.

${ }^{2}$ Luomi (2015) discusses the progress and implications under the Paris climate agreement pertaining to resource-rich MENA countries.

${ }^{3}$ In the GCC context, IRENA (2016) estimates that by 2030 , carbon emissions can be reduced by a cumulative total of around 1 gigatonne (Gt), resulting in an $8 \%$ reduction in the region's per capita carbon footprint.

${ }^{4}$ Again in the context of the GCC, IRENA (2016) estimates that by achieving their renewable energy targets and plans these countries could create an average of 140,000 direct jobs every year. According to the report, in 2030 alone, close to 210,000 people could be employed in renewables. However, it is not clear under how these numbers have been derived and which segments of the supply chain will create most of these jobs.
} 

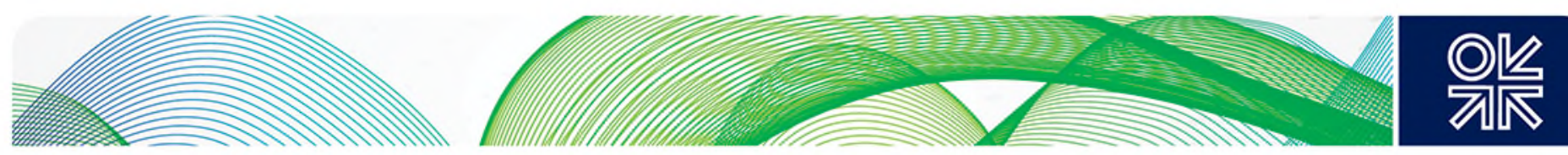

Given the context of MENA resource-rich economies as large producers and consumers of fossil fuels, this paper investigates the following two questions: (i) what are the policy solutions for incentivising investment in renewable energy in these countries; and (ii) what are the barriers to the deployment of renewable sources? Through a systematic analysis we try to provide some insights into the issues and options for renewables deployment in resource-rich MENA countries. Section 2 sets out the status of renewable energy in resource-rich MENA countries. Section 3 discusses the possible models of incentive provision for renewable investment and presents the combinatorial approach. The challenges of renewable deployment in the MENA hydrocarbon economies are discussed in Section 4. Section 5 discusses the issue of power sector reform in these countries in light of renewable policies. Section 6 concludes. 

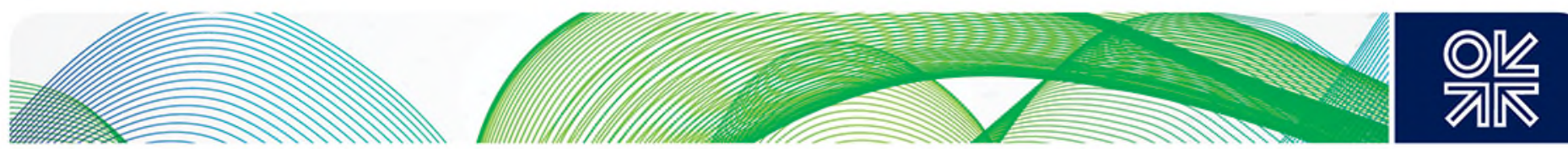

\section{The current status of renewables in resource-rich MENA countries}

The renewable energy resource potential (solar and wind) of the MENA region is well documented (IRENA Global Atlas for Renewable Energy, 2016). The GCC countries lie in the 'global sunbelt'5 with 59 per cent of their surface area estimated to have significant potential for solar deployment, and 56 per cent for wind deployment. The potential for concentrating solar power in the GCC has been estimated at 150,000 Terawatt-hours (TWh)/year, compared with GCC countries' combined electricity consumption of $470 \mathrm{TWh} / \mathrm{year}$ and their combined total primary energy demand of 4,400 TWh/year, suggesting that a large-scale expansion of renewable energy could supply the energy needs of the GCC as well as enable longer-term exports to the MENA and Europe via interconnections (Lilliestam and Patt, 2015). Other world regions identified as having comparable solar energy resources include the African continent, Indian sub-continent, South America, Central America, south-western USA, and Australia. ${ }^{6}$

A major impediment to renewables in solar-endowed regions across Asia and Africa has been the lack of capital investment, as most countries are classified as low or middle-income countries. In contrast, the MENA countries are classified as high or upper middle-income. ${ }^{7}$ Still they lag considerably behind high-income countries, and in fact even below low-income countries, in renewables investment, implying that the obstacles are also systemic rather than purely financial. Figure 2.1 shows that MENA high-income countries $(\$ 12,736$ per capita or higher) and upper middle-income countries $(\$ 4,126$ $\$ 12,735$ per capita) actually account for the lowest shares of renewables in electricity generation in the world. Nearly all MENA countries have recently announced renewable targets for the next two decades (see Table 2.1). The precise objectives behind these targets are unclear, and there are differences amongst MENA countries. However, there has been a common concern over rapidly rising domestic demand for fossil fuels (partly a result of subsidised prices) and the rising amount of domestic oil production that has to be diverted away from the export market in order to meet this demand, at a huge opportunity cost. ${ }^{8}$ Some MENA countries may therefore be aiming to meet domestic energy demand through developing their renewable resources, although the magnitude to which this is realistically achievable is as yet unclear. ${ }^{9}$ For instance, a complete shift from low-priced fossil fuels to renewables in the power sectors of MENA countries is bound to come up against some resistance from traditional utilities, as it involves fundamentally different business models. ${ }^{10}$

Figure 2.1: Renewables as a share of net electricity generation (\%) by country income classification

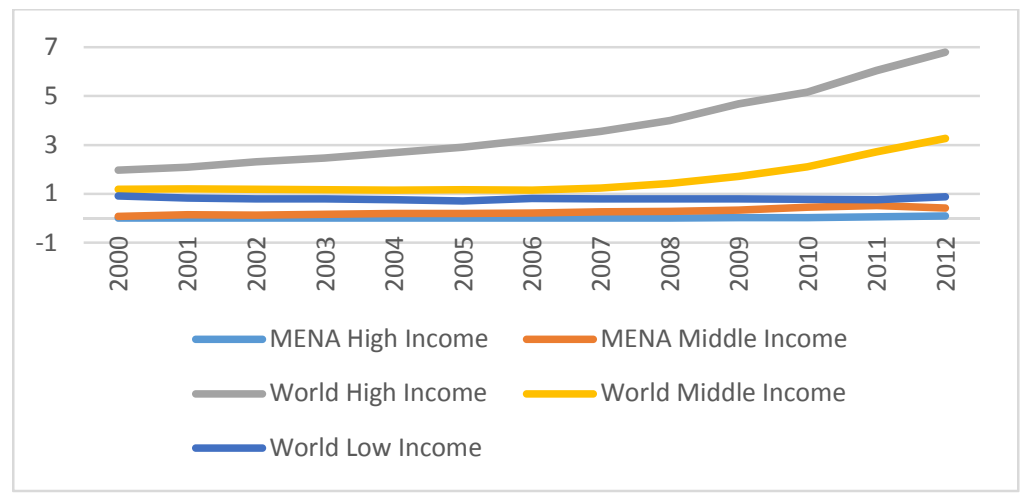

Source: World Bank (2016); EIA (2016)

\footnotetext{
${ }^{5}$ See IRENA (2016).

${ }^{6}$ Based on $\mathrm{kWh} / \mathrm{m}^{2}$ from solargis.info

7 With the exception of Morocco, classified as low-middle-income.

${ }^{8}$ Domestic consumption of oil in the Middle East has risen from $5.2 \mathrm{mb} / \mathrm{d}$ to $9.6 \mathrm{mb} / \mathrm{d}$ between 2000-2015, growing at a similar compound average annual rate as oil production.

${ }^{9}$ http://www.renewableenergyworld.com/articles/2013/01/inside-mena-countries-solar-energy-plans.html

${ }^{10}$ Section 5 of this paper discusses this in greater detail.
} 

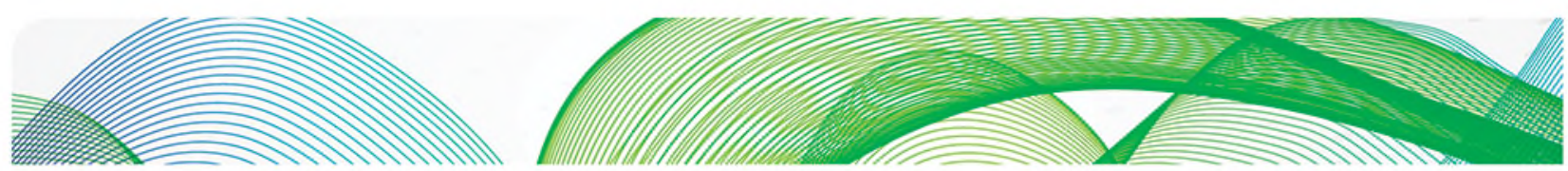
O는

Table 2.1: MENA Domestic Targets on Renewable Energy

\begin{tabular}{|c|c|c|}
\hline \multicolumn{2}{|r|}{ Target } & \multirow{2}{*}{$\begin{array}{l}\text { Date } \\
2030\end{array}$} \\
\hline Kuwait & $15 \%$ of electricity demand (generation) & \\
\hline $\begin{array}{l}\text { Saudi } \\
\text { Arabia }\end{array}$ & $9.5 \mathrm{GW}$ of renewable energy & 2023 \\
\hline UAE & $\begin{array}{l}24 \% \text { clean energy (including nuclear) in energy mix by } 2021 \text {; Abu } \\
\text { Dhabi-7\% of capacity by } 2020 \text {; Dubai- } 7 \% \text { capacity by } 2020 \text { and } 15 \% \\
\text { by } 2030 \text { (versus 'Business As Usual') }\end{array}$ & $\begin{array}{l}2021, \\
2030\end{array}$ \\
\hline Oman & - & - \\
\hline Qatar & $1.8 \mathrm{GW}$ solar ( $16 \%$ of generation) by $2020 ; 10 \mathrm{GW}$ solar PV by 2030 & $\begin{array}{l}2020 \\
2030\end{array}$ \\
\hline Bahrain & $5 \%$ of installed capacity & 2020 \\
\hline Iran & $5 \mathrm{GW}$ wind and solar capacity & 2020 \\
\hline Morocco & $42 \%$ of installed capacity by 2020 ; including $2 \mathrm{GW}$ solar $\& 2 \mathrm{GW}$ wind & 2020 \\
\hline Jordan & $10 \%$ of generation & 2020 \\
\hline Egypt & $20 \%$ of generation & 2020 \\
\hline Yemen & $15 \%$ of generation & 2025 \\
\hline Algeria & $20 \%$ of generation & 2030 \\
\hline Tunisia & $25 \%$ of capacity & 2030 \\
\hline
\end{tabular}

Source: IRENA (2013; 2016); Mittal (2016); IEA (2016)

In the last few years, most of these countries have announced various policies to support their renewables programmes. Some plans have been translated into projects with countries like the UAE leading the development of large-scale projects such as Abu-Dhabi's $100 \mathrm{MW}$ Shams CSP plant (operational since 2014) and the $13 \mathrm{MW}$ phase 1 of Mohammed bin Rashid Al Maktoum (completed in 2013). Other projects (in which bidders have been invited or selected) in the pipeline include UAE's phase 2 (200 MW) and phase 3 (800 MW) of Mohammed bin Rashid Al Maktoum, Noor 1 Solar PV plant (350MW), Kuwait's Shagaya Solar Thermal project (50 MW), and Saudi Arabia's Al-Aflaj 50 MW solar PV plant. ${ }^{11}$ Companies in the region have also been offering some of the world's lowest prices for developing solar energy. ${ }^{12}$ In many cases, however, renewable support policies are yet to be fully implemented. Given that the combined share of non-hydro renewables in generating capacity for MENA countries was around 1 per cent in 2014 (see Table 2.2), the targets have extremely ambitious timeframes, and face significant challenges given current high levels of hydrocarbon resource dependency.

\footnotetext{
${ }^{11}$ Saudi Arabia's state electricity utility has been seeking bids from international developers to build two 50 MW solar PV plants. 12 Phase 2 of Mohammed bin Rashid Al Maktoum Solar Park was auctioned at 5.85 US cents/ kWh, amongst the lowest in the world. Dubai's DEWA reportedly received 5 bids from international firms to build the third phase of the park, the lowest of which is 2.99 US cents/kWh (MEES, 2016b).
} 

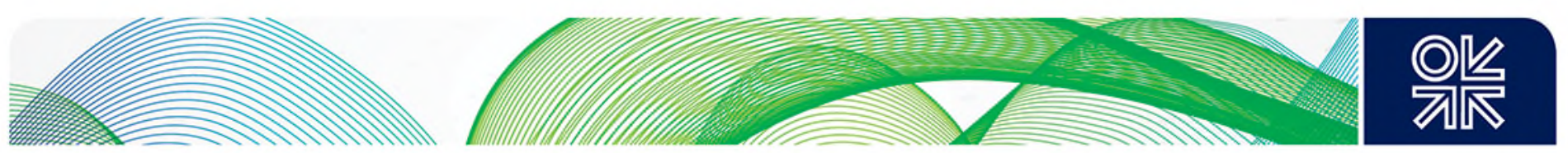

Table 2.2: Renewables (ex-Hydro) Electric Installed Capacity in MENA Countries,

\begin{tabular}{|c|c|c|c|c|c|c|c|}
\hline & $\begin{array}{l}\text { Wind } \\
\text { MW }\end{array}$ & $\begin{array}{l}\text { So- } \\
\text { lar } \\
\text { PV } \\
\text { MW }\end{array}$ & $\begin{array}{l}\text { So- } \\
\text { lar } \\
\text { CSP } \\
\text { MW }\end{array}$ & $\begin{array}{c}\text { Other } \\
\text { Renewables } \\
\text { MW }\end{array}$ & $\begin{array}{c}\text { Total } \\
\text { Renewables } \\
\text { Installed } \\
\text { Capacity } \\
\text { Megawatts }\end{array}$ & $\begin{array}{l}\text { Renewables } \\
\text { as } \% \text { of Total } \\
\text { Installed } \\
\text { Capacity }\end{array}$ & $\begin{array}{c}\text { Total } \\
\text { Installed } \\
\text { Capacity } \\
\text { Gigawatts }\end{array}$ \\
\hline Algeria & 10 & 7.1 & 25 & 0 & 42.1 & 0.24 & 17.24 \\
\hline Bahrain & 0.5 & 5 & 0 & 0 & 5.5 & 0.14 & 3.97 \\
\hline Egypt & 610 & 15 & 20 & 0 & 645 & 2.05 & 31.45 \\
\hline Iraq & 0 & 0 & 0 & 0 & 0 & 0.00 & 13.28 \\
\hline Iran & 135 & 34 & 0 & 6.8 & 175.8 & 0.00 & 70.03 \\
\hline Jordan & 1.45 & 13.6 & 0 & 3.5 & 18.55 & 0.52 & 3.56 \\
\hline Kuwait & 0 & 1.8 & 0 & 0 & 1.8 & 0.01 & 14.99 \\
\hline Lebanon & 0.5 & 1.6 & 0 & 0 & 2.1 & 0.08 & 2.50 \\
\hline Libya & 0 & 5 & 0 & 0 & 5 & 0.10 & 5.15 \\
\hline Morocco & 750 & 15 & 20 & 0 & 785 & 10.21 & 7.69 \\
\hline Palestine & 0.7 & 4 & 0 & 0.2 & 4.9 & 3.50 & 0.14 \\
\hline Qatar & 0 & 1.2 & 0 & 40 & 41.2 & 0.47 & 8.75 \\
\hline $\begin{array}{l}\text { Saudi } \\
\text { Arabia }\end{array}$ & 0 & 19 & 0 & 0 & 19 & 0.03 & 61.87 \\
\hline Sudan & 0 & 0 & 0 & 0 & 0 & 0.00 & 2.26 \\
\hline Syria $^{13}$ & 0.15 & 2 & 0 & 0 & 2.15 & 0.04 & 4.80 \\
\hline Tunisia & 245 & 20 & 0 & 0 & 265 & 6.12 & 4.33 \\
\hline$U A E$ & 0 & 33 & 100 & 1 & 134 & 0.46 & 28.96 \\
\hline Yemen & 0 & 3 & 0 & 0 & 3 & 0.35 & 0.85 \\
\hline MENA & $\begin{array}{r}1,72 \\
8\end{array}$ & 146 & 165 & 52 & 1,974 & 1.0 & 283 \\
\hline
\end{tabular}

Source: RCREE/AFEX (2015); MEES (2015); MOEM (2016); AOGD (2015); SHANA (2015)

In this paper, we focus on the MENA region's resource-rich economies and we mainly consider nonhydro renewables. Resource-rich economies of the MENA region are locked into a cycle of dependency on fossil fuels, arguably due to two primary interconnected factors; namely:

- Rising domestic hydrocarbon consumption on the back of low (subsidised) prices and plentiful hydrocarbon (oil/gas) reserves; and,

- Rising dependence on oil and gas export revenues to meet residential energy consumption and finance domestic economic activity.

On the one hand, the above two factors underpin the case for a move to renewables and away from fossil fuels. However, these factors arguably also reinforce resource dependency by further entrenching the use of fossil fuels in the system and constraining the amount of government revenues available to invest in renewables - making it difficult for these countries to break away from the cycle and making it harder for the penetration and scaling up of renewable energy. Figure 2.2 shows this resourcedependency using three ratios and sets out the countries on which much of the discussion on the challenges to renewables deployment focuses. The first column from left illustrates production to consumption ratio of oil and natural gas liquids (NGLs). A lower ratio implies that a larger proportion of production is used to meet domestic consumption. The middle column shows the percentage

${ }^{13}$ Limited data availability. 

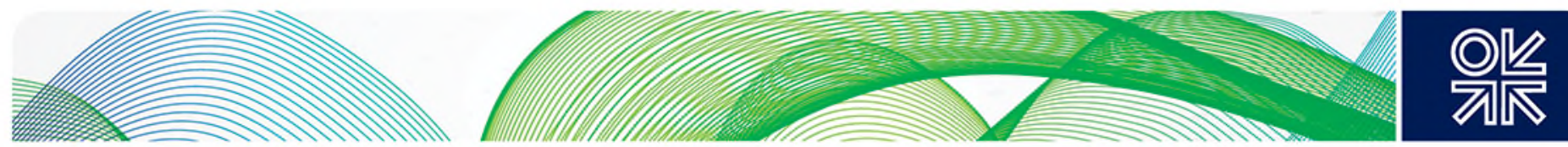

contribution of oil revenues to total government revenues, and the third one depicts the percentage of oil export revenues to GDP - a higher percentage being indicative of higher resource dependency in both cases. We exclude Libya, Iraq and Yemen from our discussion on the basis that they are extraordinary cases, due to prevailing geopolitical conflicts. We therefore focus largely on the remaining countries in Figure 2.2 and specifically on the largest economies (with nominal GDP in excess of $\$ 100$ $\mathrm{Bn}^{14}$ ) - Kuwait, Qatar, Saudi Arabia, UAE ${ }^{15}$, Algeria and Iran - in our discussions in the paper.

Figure 2.2: An assessment of resource dependency in resource-rich MENA Countries

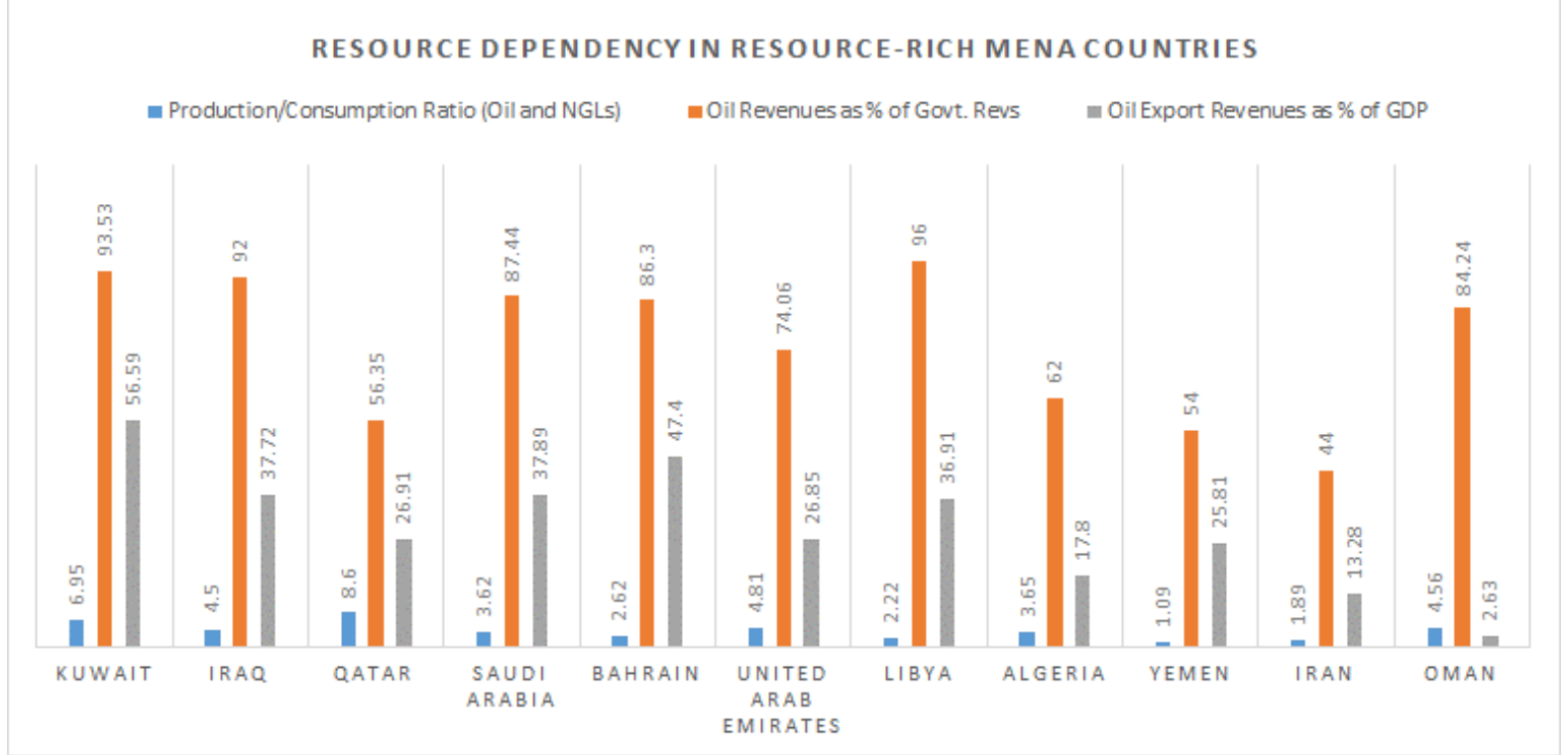

Source: OPEC ${ }^{16}$; Nakhle (2015); ENI (2015)

\footnotetext{
${ }^{14}$ Oman and Bahrain do not fall into this category.

${ }^{15}$ We focus largely on Abu Dhabi, the largest Emirate, holding over 90 per cent of the UAE's oil reserves.

${ }^{16} \mathrm{http}: / /$ www.opec.org/opec_web/en/about_us/169.htm
} 

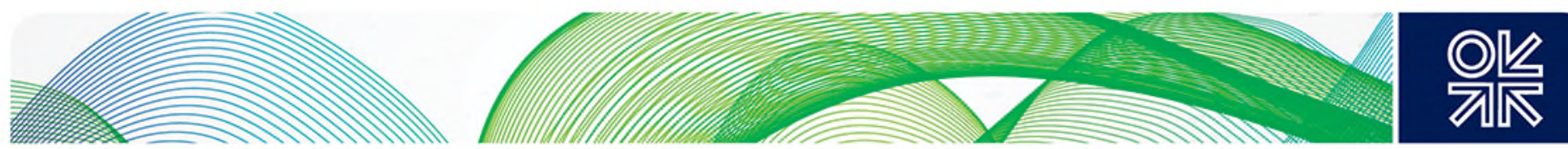

\section{Incentivising renewable deployment}

Although governments of MENA hydrocarbon economies may have different objectives to achieve by deploying renewables, the solution always involves creating incentives and eliminating or lowering the barriers to investment. The region's governments have historically played a significant role in supplying various forms of energy services and the main energy companies in these countries are still stateowned. Therefore, the solution to the challenge of renewable deployment implicitly defines the role of the government. The nature of barriers in resource-rich countries are to some extent similar to other developing countries, but the options for investment incentives are different because of their dependency on oil/gas export revenues and huge domestic consumption of subsidised fossil fuels.

Figure 3.1 presents a stylised framework for promotion of renewable energy in the generation mix. As seen from the figure, the government needs to design appropriate policies to tackle deployment barriers in the areas of grid connection and management, institutional challenges and risk and uncertainties. At the same time, governments must design policies that create incentive for investment. There are two extreme policy solutions to incentivise renewable investment in resource-rich countries. In one approach, the government introduces a full renewable subsidy programme (in addition to the current fossil fuel subsidies) and steers investment towards specific renewables. This requires long-term support and commitment on the part of government in order to create investor confidence. In the other case, the government eliminates barriers and lets economics determine market outcomes with respect to the quantity and type of renewable technologies installed. This requires the complete removal of fossil fuel subsidies (and internalising the cost of externalities) so that those forms of renewable technologies that are already competitive can kick in.

Figure 3.1: A stylised model of renewable enhancement

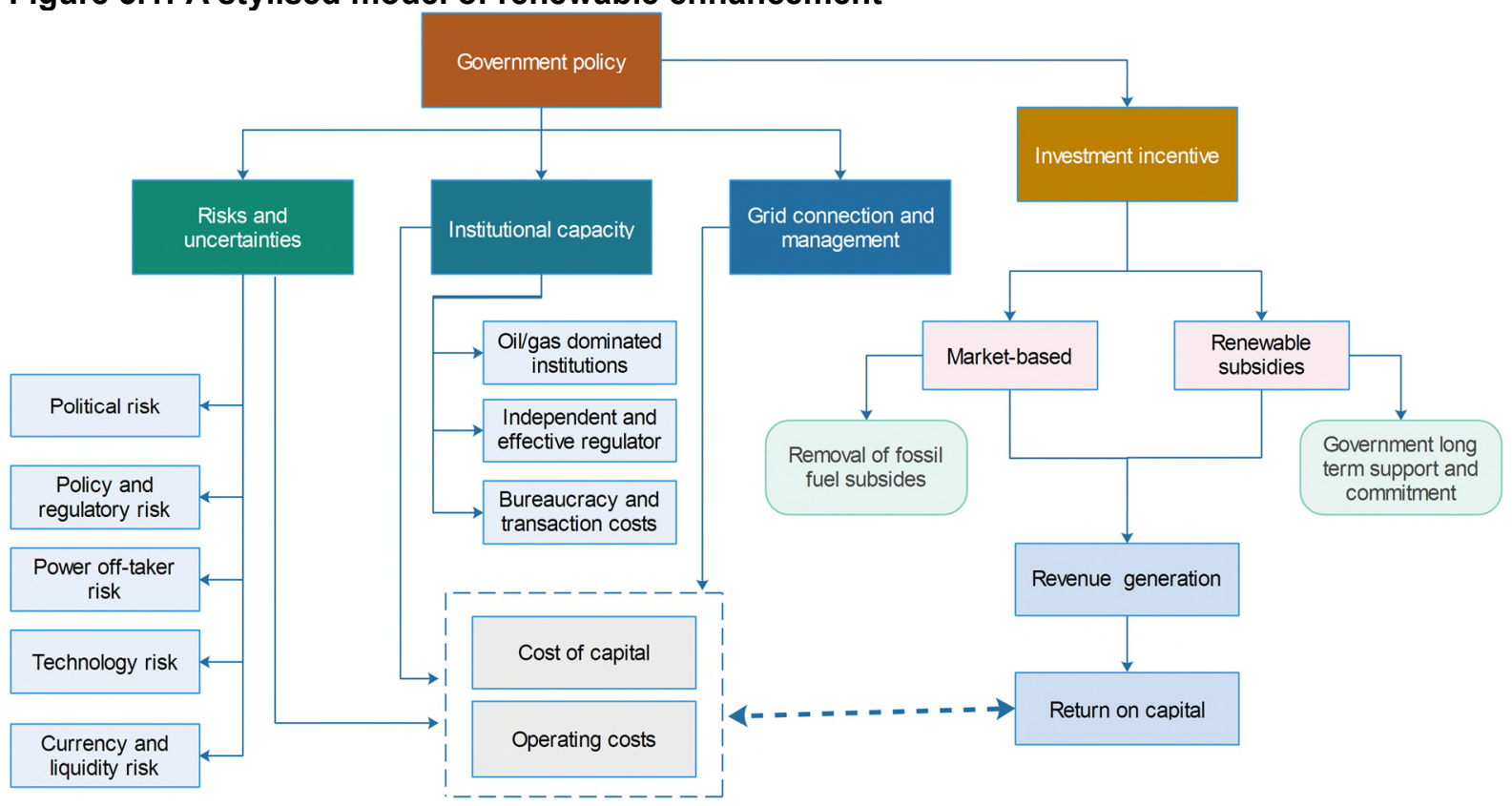

Source: Authors

The market-based strategy is usually referred to as the 'first best' solution in the literature whereas the subsidy based approach is called the 'second best'. However, we assert that both these approaches are polar solutions on a policy instrument spectrum. More market-based approaches result in political challenges, whereas moving towards a fully subsidised renewable programme increases economic pressures. Recent attempts at energy pricing reforms in the GCC countries are illustrative of these 

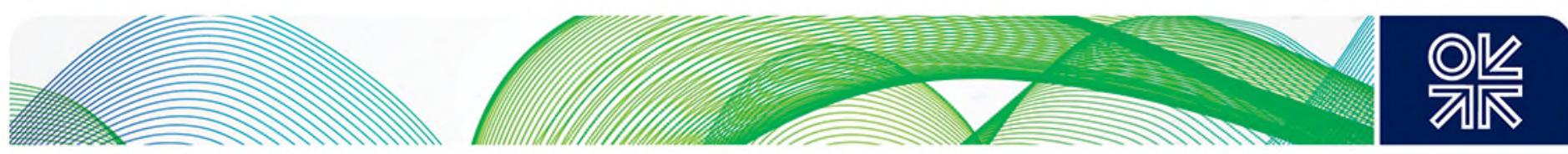

pressures..$^{17}$ Therefore, there is a fundamental trade-off between these two polar solutions in resourcerich countries. In practice this means that polar solutions are not implementable in their pure forms in these countries. Therefore, we argue that investment incentives for renewable deployment in resource rich countries of MENA needs to be provided through a combinatorial approach, which involves partial energy price reform and partial subsidy programme. In what follows, we discuss in more detail the two polar solutions and highlight some of the main challenges of implementing them in resource-rich MENA economies. Finally, we present the combinatorial approach, which potentially avoids the challenges of two polar solutions and is more compatible with the economic and political context in these countries.

\subsection{Market-oriented approach}

As the first best solution, the market-based model is a set of measures to promote efficiency and innovation in the energy sector by means of markets and competition (as opposed to government) and facilitate private sector participation. This approach, depending on the manner of implementation, can overcome many of the economic barriers to renewables deployment and can enhance the institutional and technical capacity of the country. In practice, the first best solution involves various steps such as the removal of fossil fuel subsidies alongside addressing barriers in the areas of grid access, institutions and risk and uncertainties.

Therefore, the success of the market-oriented approach depends, to a great extent, upon the price of fossil fuels. There is a (range of) price for oil (and gas) below which the market cannot incentivise investment in renewables on its own (i.e., without government intervention). This price depends on various factors such as the levelised cost of energy (LCOE) for renewables resources, prospect for technological improvement and cost reduction of alternative resources, the heat rate of fossil fuel generators and the heat content of fossil fuels. The calculation of this price requires a detailed study for each oil and gas producing country of the region. However, for illustrative purposes and in order to highlight its importance for the market liberalisation approach, we do a back-of-the-envelope calculation. According to EIA (2015), generating $1 \mathrm{MWh}$ of electricity requires 1.73 barrels of oil or 10.11 Mcf of natural gas. ${ }^{18}$ On the other hand, IRENA (2016) estimates the LCOE for a utility scale solar PV in the Middle East to be between \$58-100/ MWh..$^{19}$ Using the lowest LCOE for PV technology (i.e., $\$ 58 / \mathrm{MWh}$ ) we conclude that oil needs to be at least at $\$ 34 / \mathrm{bbl}$ and gas needs to be a minimum of $\$ 5.7 / \mathrm{Mcf}$ for the market to incentivise renewables deployment without any subsidy and government support. ${ }^{20}$ If the upper bound for levelised cost of solar is adopted, the oil price should be at least $\$ 57 / \mathrm{bbl}$ and the natural gas price should be at least $\$ 9.89 /$ Mcf. The LCOE ignores the costs of integration, implying that if the cost of dealing with intermittency is taken into account, the prices of oil and gas need to be even higher. This calculation is of course very simplistic and sensitive to the aforementioned assumptions; it is sufficient to make the point that a pure market-based approach depends on the price of competing fuels.

\subsubsection{Removing fossil fuel subsidies to enable markets}

Fossil fuel subsidies are often justified on the basis that they provide protection for vulnerable consumers and improve the competitiveness of energy intensive industries. But they are also the main

\footnotetext{
${ }^{17}$ For instance, in January 2015, in response to fiscal pressures from falling oil revenues, Kuwait's government increased diesel, kerosene, and aviation fuel prices. However, it faced political opposition and public protests, and eventually reinstated the old prices a few weeks after the announcement, for some users (Fattouh et al, 2016).

${ }^{18}$ Assuming the heat rate of petroleum to be $10,156 \mathrm{Btu} / \mathrm{kWh}$ and natural gas to be $10,408 \mathrm{Btu} / \mathrm{kWh}$. Fuel heat content is assumed to be 1,029,000 Btu per 1,000 cubic feet (Mcf) for Natural gas and 5,867,946 Btu per Barrel (42 gallons) for Petroleum.

19 The lowest estimate is based on the latest auction on the second phase of Mohammed bin Rashid

Al Maktoum Solar Park which cleared at 5.85 US cents/ kWh but the highest estimate is based on project level data and expert opinion (IRENA, 2016).

${ }^{20}$ Some have estimated the break-even price as low as $\$ 23 / \mathrm{bbl}$ for oil and \$4/MMBtu for natural gas.

(http://www.thenational.ae/business/energy/robin-mills-remarkable-solar-bids-in-dubai-should-spur-on-other-gulf-nations)
} 

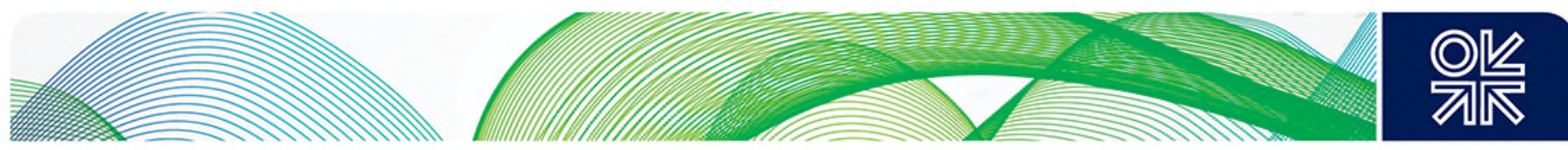

barriers to renewables deployment and market functioning as under-pricing of fossil fuels incentivises their consumption at the expense of renewable energy. ${ }^{21}$ In practice, subsidies have created an 'incumbent advantage', slowing down not only deployment of renewables but also learning rates and cost reductions. There is evidence suggesting that the relative cost advantage of wind and solar technologies due to favourable climatic conditions in MENA countries is obscured by fossil fuel subsidies (Bridle et al, 2014).

The measurement of subsidies remains problematic - there is no commonly agreed definition of what constitutes a subsidy, which is evident in the continued inability of major international organizations to agree on common terms (El-Katiri and Fattouh, 2015). The IMF (2015) nevertheless estimates that pretax MENA energy subsidies (defined as the difference between consumer prices and the costs of supply) amounted to $\$ 154 \mathrm{Bn}$ in 2015 (46 per cent of global pre-tax energy subsidies) or 4.5 per cent of combined MENA GDP. It further estimates that on the basis of post-tax energy subsidies (pre-tax subsidies plus an environmental tax and a consumption tax), petroleum, natural gas and coal account for the largest share (around 89 per cent), whereas electricity subsidies account for 11 per cent. ${ }^{22}$ Of the large resource-rich MENA countries, Iran accounted for the highest level of subsidies measured by this metric, at 15 per cent of GDP, and Qatar for the lowest (1.64 per cent), with Saudi Arabia's subsidies estimated at 9.3 per cent of GDP. ${ }^{23}$ MEES (2016d) estimates that in Kuwait, 70 per cent of the total subsidy allocation of $\$ 11.9 \mathrm{Bn}$ in 2015 went to petroleum products (especially gasoline) and electricity. These figures, however, should be treated with caution, given the many caveats in using the price-gap approach in some contexts (El-Katiri and Fattouh, 2015). The links between fossil fuel subsidies and electricity subsidies are also pertinent in determining the competitiveness of renewables. With fossil fuel subsidies, it is not only harder for renewables to compete within the existing generation sources, but also it is harder for electricity to compete with fossil fuels in end markets - particularly transportation and buildings. ${ }^{24}$

Another metric for illustrating the magnitude of subsidies is the difference between the Levelised Cost of Energy (LCOE) and retail electricity tariffs in the power sector on a per kilowatt-hour basis. Table 3.1 partially illustrates this using data from various sources. It is evident from the table that at the estimated LCOE, solar is just about competitive in the UAE, but cannot compete with heavily subsidised fossil fuels in many other MENA countries at the estimated retail tariffs. In a country such as Iran, which has already started reforming energy prices, the retail electricity tariff is well below the costs of production for most range of consumptions. The high retail tariff is only for very high levels of electricity consumption (and maximum contracted capacity for industrial and commercial users) something which does not include most end-users. Additionally, the depreciation of the Iranian Rial in recent years meant that the price reform in practice did not lead to a major adjustment of real energy prices, given the opportunity cost of using fossil fuels in power generation.

\footnotetext{
${ }^{21}$ Criticisms of subsidies include: pressure on government budgets that leads to budget cuts elsewhere, low cost recovery in electricity, adverse environmental impacts, and a disproportionate amount of benefits for high income deciles. For instance, the poorest quintile in Egypt, Jordan, Mauritania, Morocco, and Yemen receives only about 1-7 per cent of total diesel subsidies, while the richest quintile received subsidies of 42-77 per cent of the total (El-Katiri and Fattouh, 2015; Sdralevich et al., 2014). ${ }^{22}$ Each of these subsidies (petroleum, natural gas, coal and electricity) refers to the difference between the cost of supply and the price of the product plus an assumed environmental tax and consumption tax (IMF, 2015). However, it must be noted that this is simply one estimate/measure of subsidies and may not be entirely accurate.

${ }^{23}$ Saudi Arabia's total energy subsidy bill in 2015 was $\$ 61 \mathrm{Bn}$, including $\$ 23$ Bn each for diesel and electricity, and $\$ 9.5$ for gasoline MEES (2016c).

${ }^{24}$ Due to the lack of transparent data, it is difficult to differentiate accurately between fossil fuel subsidies and electricity subsidies in the MENA resource-rich countries.
} 

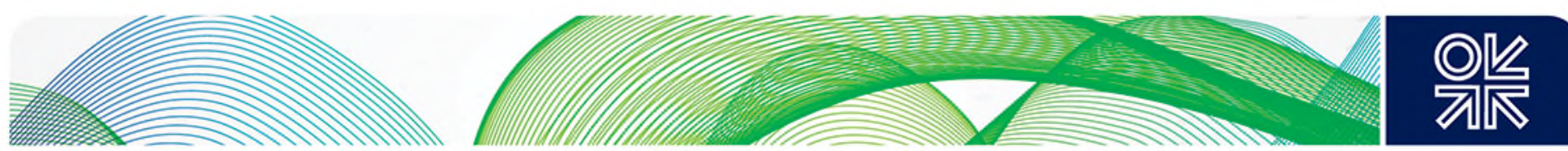

Table 3.1: Renewables LCOE versus retail tariffs in resource rich MENA countries LCOE for recent projects

\begin{tabular}{|c|c|c|c|c|c|c|}
\hline Location & Technology & $\begin{array}{l}\text { LCOE (US } \\
\text { Cents/kWh) }\end{array}$ & & Residential & Industrial & Commercial \\
\hline UAE & Solar PV & 5.85 & $\begin{array}{l}\text { Saudi } \\
\text { Arabia }\end{array}$ & 1.3 & 3.2 & 4.1 \\
\hline Jordan & Solar PV & $6.1-7.7$ & Iran & $0.4-9.6$ & $0.6-4.3$ & $2.6-10.7$ \\
\hline \multirow[t]{6}{*}{ Egypt } & $\begin{array}{l}\text { Onshore } \\
\text { Wind }\end{array}$ & $4.1-5.0$ & Kuwait & 0.7 & 0.7 & 0.4 \\
\hline & & & $\begin{array}{l}\text { UAE (Abu } \\
\text { Dhabi) }\end{array}$ & $5.6-8.7$ & 4.2 & $4.2-8.0$ \\
\hline & & & UAE (Dubai) & $7.8-12.1$ & $7.8-12.1$ & $7.8-12.1$ \\
\hline & & & Qatar & $2.2-6.0$ & $2.5-4.9$ & 2.2 \\
\hline & & & Bahrain & 0.8 & 0.8 & 3.8 \\
\hline & & & Oman & 2.6 & 5.2 & 4.2 \\
\hline
\end{tabular}

Source: IRENA (2016); IEA (2015); MoE (2015)

Although a competitive market-based approach could encourage investment in renewable projects that are economically viable and efficient, the introduction of such an approach, in a short period of time, would be challenging for a host of economic and political reasons. First, if energy price reform is carried out at a fast pace, it can result in a supply-side shock to the economy. As a consequence, energy intensive industries will be directly affected and may lose their competiveness. Other industries and businesses will be affected indirectly as a result of a rise in the general level of prices in the economy. For example, following the announcement of energy price reform in Saudi Arabia, a number of listed companies announced that their cost structures would be impacted - the petrochemical giant SABIC reported a 5 per cent annual increase in its cost structure (Fattouh et al, 2016). Likewise, the demand side may respond with a sudden drop in consumption, and may or may not recover. Therefore, a large increase in the price of energy can lead to inflation, and potential economic slowdown.

On top of the above, energy price reform is a politically sensitive issue in the MENA's resource-rich monarchies. Any measures perceived as disruptive to the established structure of political institutions potentially risks leading to social discontent. The implicit social contract between rulers and citizens of these countries endows the governments with the privilege of governing hydrocarbon resources in exchange for the redistribution of resource rents (Fattouh et al, 2016). A change in policy such as the removal of fossil fuel subsidies, which in the short run takes away wealth from consumers, may be perceived as the breakdown of the implicit social contract, and could face social opposition. Recent experience of energy pricing reform in the GCC countries however shows that the social contract may not be as 'inelastic' as perceived; in the face of falling oil prices and increasing fiscal pressures, gradual energy pricing reform that is accompanied by clear communication to the public and balanced by compensatory measures for lower-income consumers and mitigation measures for the private sector, could sustain a more 'elastic' social contract (Fattouh et al, 2016).

\subsubsection{Pricing carbon (internalising externalities)}

A carbon tax can boost the incentive for renewables in a market-oriented fashion. This is helpful specifically when energy price reform alone cannot provide sufficient incentives needed for renewables deployment. The carbon tax is a direct tax on burning fossil fuels (in power generation for example) and

\footnotetext{
${ }^{25}$ A note on tariffs in Iran: the industrial tariff does not include water and agriculture. Also, the industrial and commercial tariffs are categorised based on maximum contracted capacity (differs based on being lower or higher than $30 \mathrm{~kW}$ ). Residential tariff is an inclined block tariff and along with commercial tariff differs for cold and hot regions of the country (lower in hotter regions). The rate of exchange used for conversion is $1 \mathrm{USD}=30550$ Iranian Rials.
} 

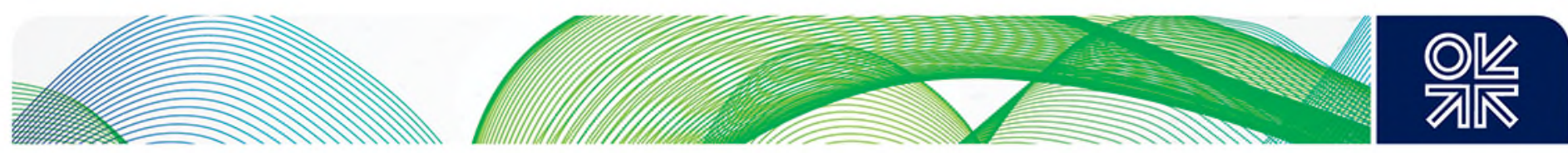

thus it internalises the cost of externalities. From an economic perspective, it is the most effective way to incentivise renewable energy because it relies on the free market to choose the most efficient clean energy innovations and investments. The side effect of a carbon tax is, however, that it adversely impacts the economy in the short run and hurts low-income consumers. One solution for this would be to redistribute carbon tax revenues to alleviate electricity bills and reduce other taxes (such as income tax and capital gains tax). ${ }^{26}$

However, the main problem of taxation in the MENA resource rentier economies goes beyond the aforementioned distributional and economics challenges. First, many of these countries do not have an established tax collection system and the relevant institutions basically do not exist. For example, in the GCC countries, tax revenues (primarily from corporate tax, trade tax and property taxes) comprise a very small fraction of government revenues. ${ }^{27}$ In addition, taxation is a politically sensitive issue everywhere, but even more so in resource-rich countries because introducing new taxes completely undermines a government's source of legitimacy and public support which are obtained through the distribution of resource rents. Therefore, under the current conditions, it is very unlikely that a policy based on a carbon tax would be possible in these countries - something which even developed economies with a long tradition of taxation struggle to establish.

\subsection{Fully subsidised renewable energy programme}

In contrast with the market-based approach, a fully subsidised renewable programme can incentivise investment in renewables by offering various forms of direct and indirect financial incentives. This approach requires a heavy involvement of government in the process of renewables deployment from designing to implementation and management of support schemes. There is a wide range of schemes that governments can choose from, some of which can be implemented in non-liberalised electricity sector structures, and alongside fossil fuel subsidies. Overall, renewable policy support policies can be broadly classified into production based and investment based schemes (see Figure 3.2). These two categories can be further divided into price based and quantity based models.

\section{Production-Based Support Schemes}

In price based production-oriented schemes, the renewable resource owners are incentivised based on the unit of energy produced (e.g., per kWh). The incentives can take various forms, such as production tax credit, tax reduction, feed-in-tariff (FiT), feed-in-premium (FiP) and net metering at retail price. With a production tax credit, renewable energy production is partially or totally exempted from tax liabilities during a specific year. Tax reduction is a cut in tax based on the energy produced and can include sales, value added, carbon or energy taxes. A Feed-in-Tariff (FiT) is a long-term contract (e.g., 15 years) between the government and the producer of renewable electricity in which a guaranteed payment is made for each unit of energy fed into the grid. On the other hand, a feed-in-premium is a scheme in which the owner of renewable generation receives a payment on top of what it normally receives from the sale of its energy in the electricity market. The premium can be fixed, floating or can have a cap and floor. Net metering is a policy that allows the owner of a small renewable facility to satisfy its demand at any time through onsite generation, and feed into the grid when there is surplus energy. The exact form of this scheme varies in different countries but the general principle is that the net consumption (which can be positive or negative) is tracked through a bi-directional meter. The consumer pays a retail electricity tariff when the net consumption is positive during the billing period. On the other hand, when the net consumption is negative the consumer will be compensated at retail tariff (or wholesale price) or can bank the surplus energy credit for the following period.

\footnotetext{
${ }^{26}$ This is sometimes referred to as a revenue-neutral carbon tax, such as the one introduced in British Columbia, Canada. ${ }^{27}$ Total tax revenues as a percentage of GDP in the GCC is as follows: Oman (2.8\%), UAE (2.5\%), Qatar (1.7\%), Saudi Arabia $(1.4 \%)$, Kuwait $(0.8 \%)$ and Bahrain $(0.6 \%)$ (Fattouh et al., 2016).
} 

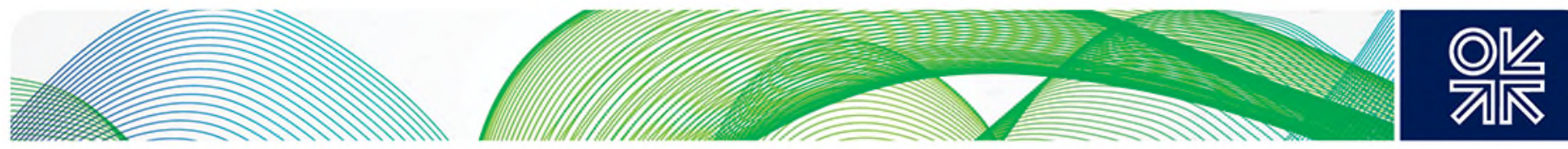

Figure 3.2: Classification of renewable support schemes

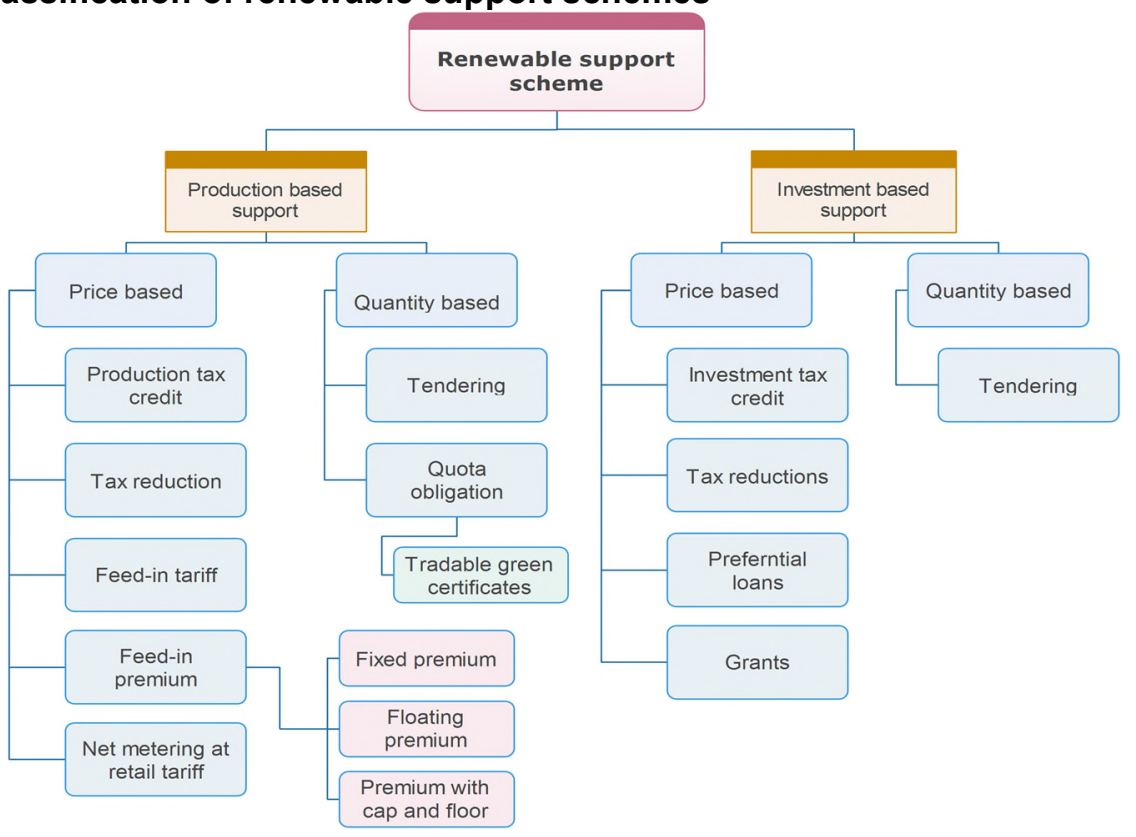

Source: Authors

The production based support scheme can be quantity-oriented. This is usually in the form of tendering or quota obligations. In the tendering model, the government specifies the quantity of renewable energy that needs to be procured and runs an auction in order to discover the price (per kWh for example) and grant contracts to the most efficient suppliers. The quota obligation is a scheme in which electricity suppliers are obliged to procure a certain percentage of their energy supplied from renewables. A tradable green certificate (TGC) (alternative names for TGC are renewable energy credit or renewable electricity certificate, tradable renewable certificate or green tags) is issued for each unit of energy produced by renewables (e.g., MWh). The TGCs are traded in a secondary market and the owner of renewable facilities is entitled to the revenue from TGCs on top of the revenue from the sale of their energy in the electricity market. The electricity suppliers are required to surrender a sufficient number of TGCs in order to comply with their obligations. A penalty is imposed (per MWh) on suppliers in the event they fail to submit the required certificates which, in practice, acts as a cap for TGC prices.

\section{Investment-Based Support Schemes}

The renewable support scheme can be based on investment rather than production. Similar to the previous case, the investment oriented support models are either price based or quantity based. Pricebased schemes are investment tax credit, tax reduction, preferential loans and grants. On the other hand, investment oriented quantity based schemes can be in the form of tendering. Investment tax credit and tax reduction schemes are similar to the equivalent schemes in the production-oriented model with the difference that they are based on the amount of capital expenditures on the renewable energy technologies rather than on energy produced. Preferential loans are mechanisms in which governments cover part of the interest rate (e.g., $50 \%$ ) for the finance provided by commercial banks or other financial institution for renewable energy technologies. If the perceived project risk is high, the government may provide a guarantee to cover a share of the outstanding loan principal in order to lower the capital cost to investors. Investment oriented quantity based schemes are when the government sets the capacity of projects and runs an auction to identify the most efficient investor (per MW for example). The government then subsidises the investment (per MW) cost or partially finances the project in return for an equity ownership in the project. 

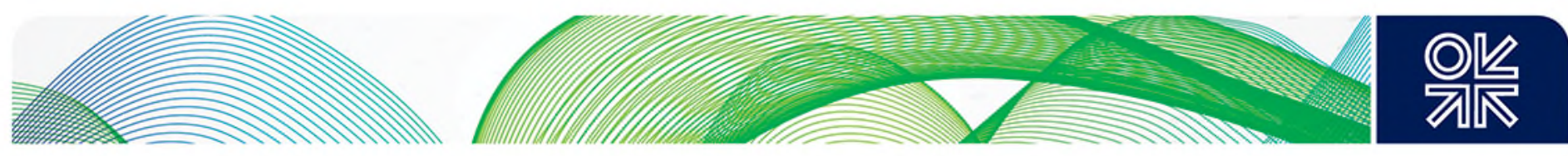

\section{No One Solution Fits All}

Although from an economic perspective, renewable support schemes imply further distortion to the electricity market, this approach is more likely to achieve a particular renewable target. Additionally, it can be used to achieve other government objectives such as job creation and growth of domestic industry. For instance, in order to incentivise the use of domestically manufactured products, equipment and technologies, Iran applies a 15 per cent increase to the standard rate of power purchase agreements of those renewable plants that are sourced locally. ${ }^{28}$ In a similar manner, KACARE (King Abdullah City for Atomic and Renewable Energy) incorporates local content stipulations in competitive procurement and provides a fiscal incentive for local employment.

The type of schemes that can be adopted by resource-rich economies depends on various factors such as the scale of project, degree of maturity of renewable technology, size of renewable targets, the extent of financial resource constraints, risk attitude, presence of relevant institutions and stage of electricity market liberalisation. For example, some schemes such as production tax or investment tax incentives are not suitable for small-scale projects such as rooftop solar PV installations, because households may not have such tax liabilities to offset through these incentives. For immature technologies or those that are at a demonstration stage, investment based schemes are more suitable than production-based schemes. At the same time, investment based schemes are not suitable for countries facing fiscal constraints. For risk averse investors, a scheme such as a feed-in-tariff which has full cost coverage is more suitable, as opposed to for example feed-in-premium in which subsidies partially cover the cost of a project. Furthermore, feed-in-tariffs have proved to be more successful in promoting scalability and realising ambitious renewable targets. In addition, some support policy schemes require the presence of relevant institutions: for example, a tax-based incentive is not effective in countries that do not have tax institutions or where tax systems are weak. This is specifically an issue in most resource-rich MENA economies. Further, some renewable support policy schemes such as feed-in-premiums and TGCs under quota obligations require a liberalised electricity market to be implemented, whereas others such as feed-in-tariffs can be implemented even under a monopoly market structure.

The support schemes also differ in their degree of price exposure (i.e., market risk- when it is applied in a liberalised platform), and can be technology specific or technology neutral. In order to take advantage of the best features of different support models, schemes can be combined. For instance, feed-in-tariffs can be combined with tendering to ensure efficiency, or feed-in-tariffs can be combined with tendering and contract for difference (CfD) in order to take advantage of electricity price movements. This latter model has been adopted in the UK to support renewable development as part of the recent electricity market reform. The subsidy schemes can also be distinguished based on whether they focus on incentivising the supply side (e.g., feed-in-tariff) or the demand side (e.g., quota obligation). All of these imply that governments need to make a decision about adopting appropriate forms of renewable support schemes.

An effective renewable support policy scheme for resource-rich MENA countries is one which:

- is compatible with the structure of electricity markets in the region

- promotes scalability and covers most risks that investors are exposed to

- can also be implemented in a low oil price environment (suitable for fiscally-constrained countries)

- the relevant institutions exist and

- is market-oriented to the extent possible

Table 3.2 presents the results of our analysis on the suitability of renewable support schemes for resource-rich economies. As seen from the table, except for (production-based) tendering, none of the schemes meet all of the aforementioned criteria. The second best scheme is also tendering

${ }^{28}$ http://www.wfw.com/wp-content/uploads/2016/05/WFW-Briefing-Renewable-Energy-in-Iran.pdf 

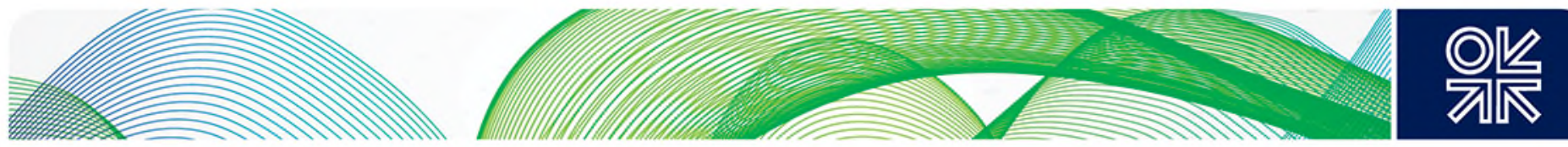

(investment-based). From an economic perspective, auctions are the most efficient method of resource allocation if a sufficient number of non-colluding bidders participate. The next best approaches, according to our analysis, are preferential loans, grants and feed-in-tariff. The remaining models are ranked fourth. This explains why tendering, grants, loans and feed-in-tariffs are the most popular schemes for renewable promotion in resource-rich MENA economies (please see Table 3.3). Netmetering based on retail tariffs, which is very popular in USA, does not require a liberalised electricity market, but needs undistorted retail electricity prices and a suitable retail tariff (e.g., a two-part tariff). This is why only the UAE has adopted it among hydrocarbon economies (see Table 3.3).

Table 3.2: Evaluation of suitability of support schemes for resource rich countries of MEA

\begin{tabular}{|l|c|c|c|c|c|c|c|}
\hline $\begin{array}{l}\text { Type of } \\
\text { scheme }\end{array}$ & $\begin{array}{l}\text { Compatible } \\
\text { with a non- } \\
\text { liberalised } \\
\text { electricity } \\
\text { system? }\end{array}$ & $\begin{array}{l}\text { Suitable } \\
\text { for large- } \\
\text { scale } \\
\text { projects? }\end{array}$ & $\begin{array}{l}\text { Full cost } \\
\text { coverage } \\
\text { for the } \\
\text { project? }\end{array}$ & $\begin{array}{l}\text { Suitable for } \\
\text { financially } \\
\text { constrained } \\
\text { countries? }\end{array}$ & $\begin{array}{l}\text { Relevant } \\
\text { institutions } \\
\text { exist? }\end{array}$ & $\begin{array}{l}\text { Market } \\
\text { oriented? }\end{array}$ & Rank \\
\hline Feed-in-tariff & $\checkmark$ & $\times$ & $\checkmark$ & $\checkmark$ & $\checkmark$ & $\times$ & 3 \\
\hline $\begin{array}{l}\text { Feed-in- } \\
\text { premium }\end{array}$ & $\times$ & $\checkmark$ & $\times$ & $\checkmark$ & $\times$ & $\checkmark$ & 4 \\
\hline $\begin{array}{l}\text { Net metering } \\
\text { at retail tariff }\end{array}$ & $\checkmark$ & $\times$ & $\times$ & $\checkmark$ & $\checkmark$ & $\times$ & 4 \\
\hline $\begin{array}{l}\text { Tradable } \\
\text { green } \\
\text { certificates }\end{array}$ & $\times$ & $\checkmark$ & $\times$ & $\checkmark$ & $\times$ & $\checkmark$ & 4 \\
\hline $\begin{array}{l}\text { Tendering } \\
\text { (production) }\end{array}$ & $\checkmark$ & $\checkmark$ & $\checkmark$ & $\checkmark$ & $\checkmark$ & $\checkmark$ & 1 \\
\hline $\begin{array}{l}\text { Tendering } \\
\text { (investment) }\end{array}$ & $\checkmark$ & $\checkmark$ & $\checkmark$ & $\times$ & $\checkmark$ & $\checkmark$ & 2 \\
\hline $\begin{array}{l}\text { Tax credit } \\
\text { (production } \\
\text { and } \\
\text { investment) }\end{array}$ & $\checkmark$ & $\checkmark$ & $\times$ & $\checkmark$ & $\times$ & $\times$ & 4 \\
\hline $\begin{array}{l}\text { Tax } \\
\text { reduction } \\
\text { (production } \\
\text { and } \\
\text { investment) }\end{array}$ & $\checkmark$ & $\checkmark$ & $\times$ & $\checkmark$ & $\times$ & & \\
\hline $\begin{array}{l}\text { Preferential } \\
\text { loans }\end{array}$ & $\checkmark$ & $\checkmark$ & $\times$ & $\checkmark$ & $\checkmark$ & $\times$ & 3 \\
\hline \begin{tabular}{l} 
Grants \\
\hline
\end{tabular} & $\checkmark$ & $\checkmark$ & $\times$ & $\checkmark$ & $\checkmark$ & $\times$ & \\
\hline
\end{tabular}

Source: Authors 
Table 3.3: Renewable support policy schemes currently adopted in the MENA

\begin{tabular}{|l|l|}
\hline Country & \multicolumn{1}{|c|}{ Support Policy announced } \\
\hline Kuwait & Competitive tenders; public investment, loans or grants \\
\hline Saudi Arabia & Competitive tenders; public investment, loans or grants \\
\hline UAE & Public investment, loans, grants, competitive tenders, net metering \\
\hline Oman & Fiscal incentives; public competitive bidding; public investments, loans, or grants \\
\hline Qatar & Public investments, loans or grants \\
\hline Bahrain & - \\
\hline Iran & FiTs, capital subsidies, soft loans \\
\hline Morocco & Competitive tenders; public investments, loans or grants \\
\hline Jordan & $\begin{array}{l}\text { FiTs, net metering; tax incentives; competitive tenders; public investments, loans, or } \\
\text { grants }\end{array}$ \\
\hline Egypt & FiTs, competitive tenders \\
\hline Yemen & Competitive bidding \\
\hline Algeria & FiTs; competitive bidding \\
\hline Tunisia & Net metering; fiscal incentives; public investments, grants or loans \\
\hline
\end{tabular}

Source: IRENA (2013; 2016)

\subsubsection{Long term government support and commitment}

Public policy commitment and long-term support play critical roles in realising ambitious renewable targets under a government subsidy programme. The government needs to reassure investors of its commitment and demonstrate that support for renewables is not just for show but an integral part of an overall strategy for energy and economic development. This can be done by, for example, integrating renewables within national energy strategies and utilising the many positive externalities created by renewables.

Along with renewable targets, which are effective means of sending signals to investors, a dedicated financial support mechanism is needed to promote investor confidence and lower the cost of capital. Priority sector lending, dedicated funding to renewable energy projects such as convertible loans and grants and guidelines for issuing green bonds are among the many examples of financial support commitment. The government can also provide other support such as technical assistance and grant funding for feasibility studies and document preparation to increase the pipeline of projects ready for investments (IRENA, 2016b).

One important lesson from Europe's experience is that frequent changes in renewables subsidy policy sends the wrong signals to private investors. For example, at the time of writing, the UK Low Carbon Contracts Company (LCCC) terminated the Contract for Difference feed-in-tariff that had been awarded to Mainstream Renewable Energy's Neart Na Gaoithe offshore wind farm in 2015. ${ }^{29}$ This unprecedented action was followed by the announcement that the Danish government may cancel a competitive auction planned for a series of nearshore wind farms. These measures have left offshore project developers on the hook for millions of Euros in upfront development capital. These types of policy 'U-turns' would be detrimental for renewable investment, specifically in the nascent markets of resource-rich MENA economies. In Egypt, for instance, the government changed regulations on international arbitration for renewables projects in May 2016, leading to considerable investor uncertainty. ${ }^{30}$ Unpredictable changes such as these need to be avoided as much as possible, and a

http://www.offshorewind.biz/2016/05/12/mainstream-disputes-neart-na-gaoithe-cfd-termination/

'Egypt's solar power upset clouds outlook for foreign investors', The Indian Express, 5 August 2016.

http://indianexpress.com/article/world/world-news/egypts-solar-power-upset-clouds-outlook-for-foreign-investors-2955324/ 

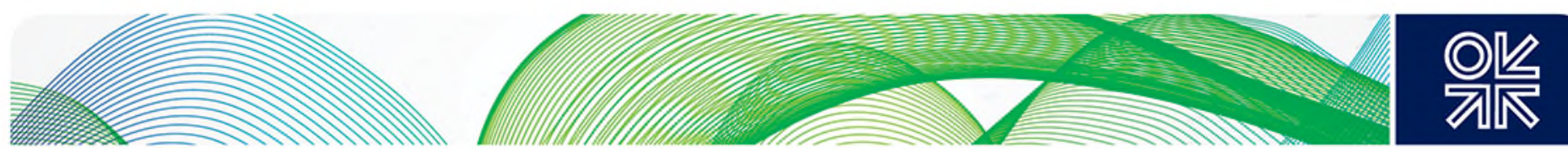

mechanism for change needs to be set out within the policy itself to avoid surprising market players. Moreover, the investors need to have enforceable contracts and a mutually agreed method of dispute resolution specified in the terms of contract (for example through international chamber of commerce (ICC)).

The cost of support schemes is an important factor which may compromise government commitment and long-term support. This is because subsidising renewables is very costly and is likely to place a huge pressure on the already tight governments' budgets in the low oil price environment. This situation will be worsened when renewable support is added to current fossil fuel subsidies which already constitute a significant part of governments' expenditures. In the aftermath of the most recent oil price fall, many oil producing countries of the MENA region ran into budget deficits. This has led nearly all these countries to embark on expenditure cuts in various sectors of economy, alongside the suspension of some planned infrastructure projects. Figure 3.3 presents the fiscal balance and gross debt as percentages of GDP for major oil and gas producing MENA countries. As seen from the figure, most countries have high gross debt and/or negative fiscal balances at the moment, and although the fiscal buffers are plentiful, they are also temporary, especially in the event of a prolonged decline in oil prices (Fattouh et al, 2016).

Therefore, given the ambitious renewable targets, along with exorbitantly high cost of fossil fuel subsidies in many of these countries, it is very unlikely that a full renewable subsidy programme would be possible especially when considering unfavourable economic conditions due to the decline in the oil price.

Figure 3.3: Fiscal balances and gross debt (\% of GDP), 2015

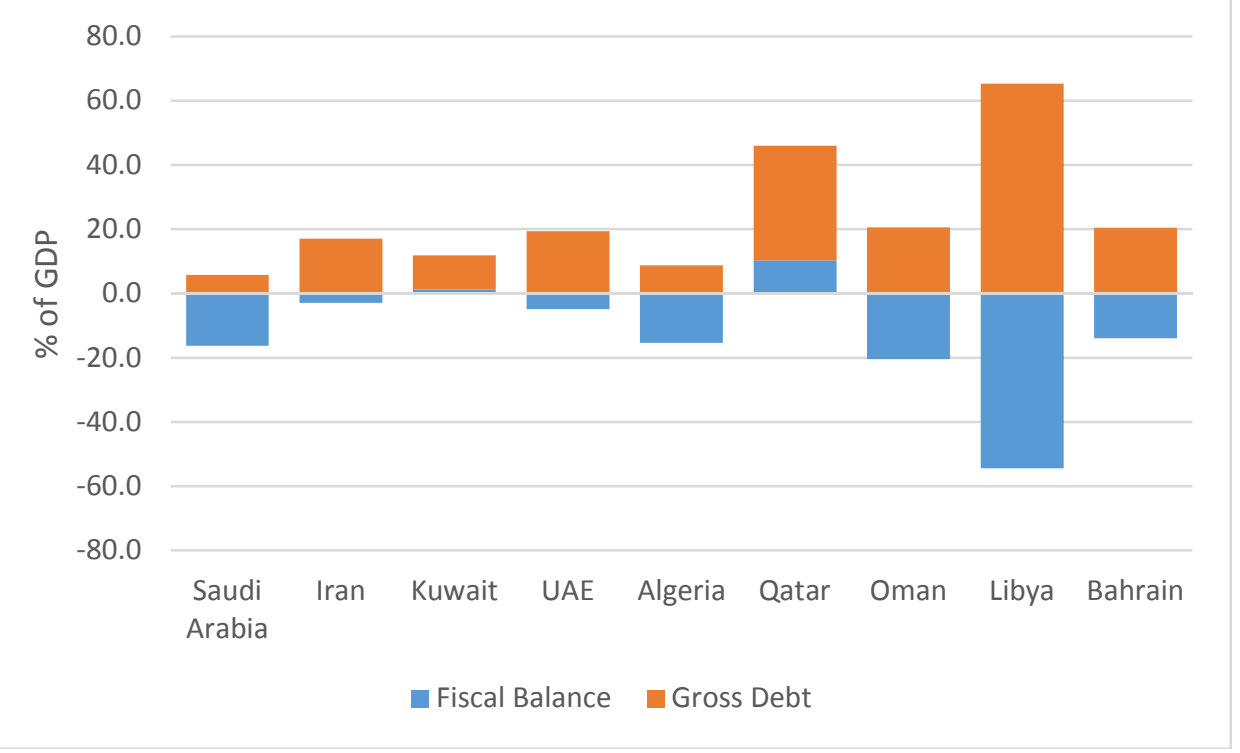

Source: IMF (2016)

\subsection{A combinatorial approach}

A long-term fully subsidised renewable energy programme, in addition to the current fossil fuel subsidies, is fiscally difficult across all resource-rich MENA economies. Similarly, the implementation of full energy price reform to enable the market, in a short period of time, would be nothing short of a revolution in these countries. Therefore, the application of polar solutions in their pure forms would be extremely challenging, if not impossible.

Any in-between strategy constitutes a combinatorial approach that takes some elements from the two polar solutions and depending on where it lies in the policy spectrum, the weight of one set of 

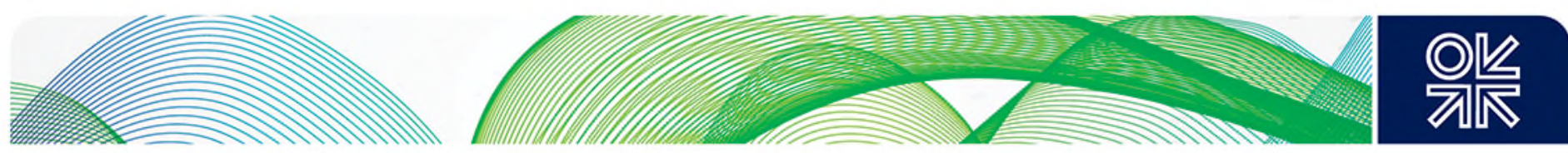

instruments (for example, market based) can be higher or lower than other instruments (direct renewable subsidies) (Figure 3.4). The combinatorial approach can be part of a dynamic process in which the countries start from the most feasible point on the proposed policy instrument spectrum, given their current context, and gradually move towards phasing out fossil fuel subsidies over the medium to long term. This not only reduces the fiscal pressure on government budgets (compared to a fully subsidised model), but also averts political risks by allowing businesses and households to slowly adapt to the new environment where energy carriers are priced at their full economic costs. The position on the policy instrument spectrum is a function of the countries' institutional setting, the state of energy price reform, fiscal situation of the government and public acceptance, among others.

\section{Figure 3.4: Policy instrument spectrum for incentivising renewable investment}

Fully subsidized renewable (in addition to fossil fuels)

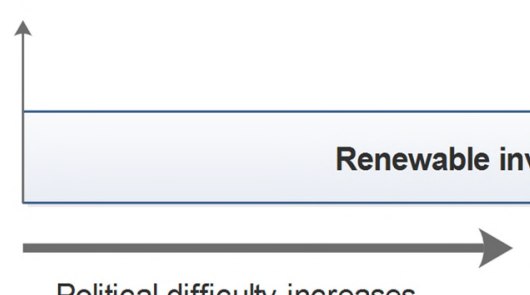

Political difficulty increases
Combinatorial approach: partial subsidies and partial energy price reform
Market based: complete removal of fossil fuel subsidies

\section{Source: Authors}

Economic difficulty increases

The combinatorial approach is compatible with current policies regarding energy price reform in the resource-rich MENA economies. In fact, the fiscal tightening from the prolonged 2014 downturn in oil prices has already led to widespread planned energy price reforms, alongside cuts in expenditure (see Fattouh et al., 2016). The UAE was the first to announce comprehensive fuel subsidy cuts in mid-2015, by linking domestic prices for gasoline and diesel to international spot market prices. Saudi Arabia hiked fuel prices for transport, power generation fuels and petrochemicals feedstock, followed by price hikes for electricity and water, in early 2016. Oman, Bahrain and Qatar all announced fuel price hikes in a flurry (MEES, 2016d). Iran carried out extensive fuel subsidy reform much earlier, in 2010, but underestimated the costs of the reform and the impact on consumer price inflation (Lilliestam and Patt, 2015). The price hikes were carried out in a very short period of time leading to increases of up to 150 per cent in some countries, generating some backlash from consumers. Consequently, some countries began 'rethinking' the manner and pace of reforms, instead opting for periodic (monthly) adjustments (Qatar, Oman) and targeting of poorer consumers (Kuwait, Saudi Arabia) through considering price differentiation by consumption volumes, and the rationing of quantities rather than providing price subsidies. Iran's 2016 budget envisaged a reduction in the number of consumers receiving cash hand outs and the revival of a fuel 'smartcard' scheme for selling gasoline at different consumption slabs (MEES, 2016e; 2016f; 2016g). Kuwait was the last MENA country to announce subsidy reforms, announcing a plan for an 83 per cent rise in some petrol prices - the first rise in 50 years - from 1 September $2016 .^{31}$

Therefore, an important feature of the combinatorial approach for incentivising renewables is that it takes not only the economic factors into account but also the political issues related to subsidies. That way, the pace of price reform can be adjusted for each individual resource-rich country based on its own context. As opposed to a fully subsidised programme which transfers the whole cost of renewable deployment to the government budget, the combinatorial approach partially relies on government and partially on the market. In a similar way, contrary to a fully market based model which transfer the political risks to government but economic risk to market agents, the combinatorial approach distributes

'Kuwait announces 'ultra' petrol price rise of 83\% - to 55 cents a litre' The Guardian, 2 August 2016. https://www.theguardian.com/world/2016/aug/02/kuwait-announces-petrol-price-hike-of-83-to-55-cents-a-litre 

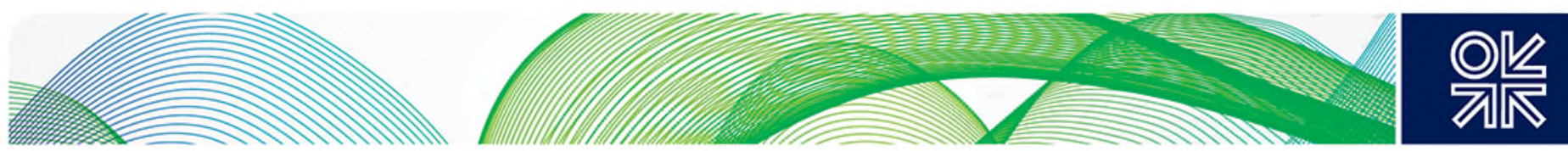

the risk between market players, government, and consumers in a more efficient way. In this sense, the combinatorial approach provides a practical way forward for the hydrocarbon economies to increase the share of renewables in their power generation mix. 

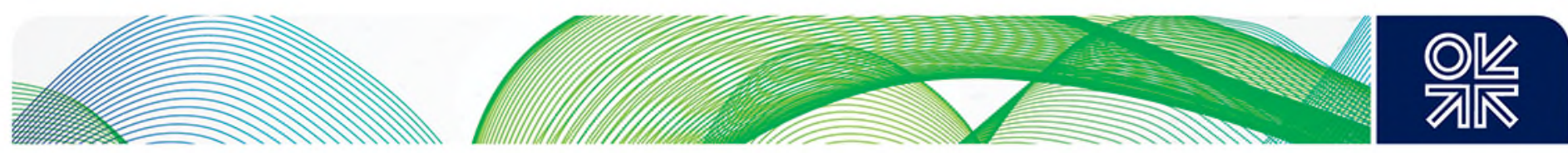

\section{Removing barriers to renewable deployment}

Creating investment incentives, through for example the combinatorial approach, is necessary but not sufficient for renewable promotion as the barriers to deployment also need to be removed. Despite the differences among MENA resource-rich countries, they share similarities in their energy sector structure and governance; hence, there are common factors that contribute to the low levels of renewable investment in these economies. We identify these barriers to be: grid connection and management, institutional challenges and risk and uncertainties.

\subsection{Grid connection and management}

A key component of energy transformation in the hydrocarbon economies of MENA region is the availability of grid infrastructure that enables electricity transmission from production to consumption areas. The lack of a national grid and/or inadequate network infrastructure can pose a serious threat to the development of renewables. In the absence of adequate grid capacity and resiliency, renewable energies may face frequent curtailment due to network and reliability constraints. Grid inadequacy is becoming an important challenge for renewables deployment even in OECD countries such as the UK. ${ }^{32}$

Furthermore, the connection cost model is important for renewable investment (shallow versus deep connection fees) -i.e., whether the grid company is responsible for the costs of grid connection and reinforcement, or the renewable project developer, and, if grid connection involves some costs then whether the investor can recover these through their tariff. In addition, investors in renewables need guaranteed access to the transmission/distribution grid under clear, transparent and non-discriminatory conditions. Priority access and priority dispatch ${ }^{33}$ are particularly important in engendering the competitiveness of renewable technologies. Since renewable projects are more dependent on geographical location than conventional generation, priority access ensures that constraints in relation to site selection can be minimised. The inaccessibility of the low voltage grid, for instance, can impede the deployment of distributed solar PV. The implication of priority dispatch is that conventional generators have to reduce their generation levels in cases of transmission congestion (RCREEE/AFEX, 2015).

The existing relatively integrated power sector structures of MENA countries pose a challenge to renewables deployment in this regard. In a highly integrated market, where the same actor handles both generation and transmission, incentives might arise to exclude generating competitors by denying grid access. Grid investment requires a suitable and stable regulatory and policy environment with appropriate incentives and long-term horizons. One approach is to specify grid access details in national-level regulations and grid codes, and to avoid case-by-case negotiations. Only a few countries in the region have specified grid access details in their regulations, and Algeria and Jordan currently include the most preferential grid access conditions for renewable projects (see Table 4.1). Saudi Arabia and Abu Dhabi have detailed grid codes but do not specify any special conditions for renewables projects (RCREEE/AFEX, 2015).

An alternative way to incentivise infrastructure investment in heavily state-owned electricity sectors is to institute some form of regulation. For instance, although the UAE does not have grid codes which are essential to attracting private generation investors, it incentivises network investment by using RPI$X$ regulation to set network tariffs for its state-owned company.

The inefficiency of grid infrastructure and operation is also reflected in levels of transmission and distribution (T\&D) losses, depicted in Figure 4.1. T\&D losses in the majority of MENA countries are far higher than comparable high-income (OECD) countries (where they average around 6 per cent), and

\footnotetext{
32 https://www.theguardian.com/business/2015/may/10/uk-electricity-grid-renewable-energy-solar-trade-association.

${ }^{33}$ In the fully liberalised electricity markets in which the payment to renewable generators is linked to the wholesale market, priority dispatch is not needed as renewable resources have natural priority because of their low marginal cost.
} 

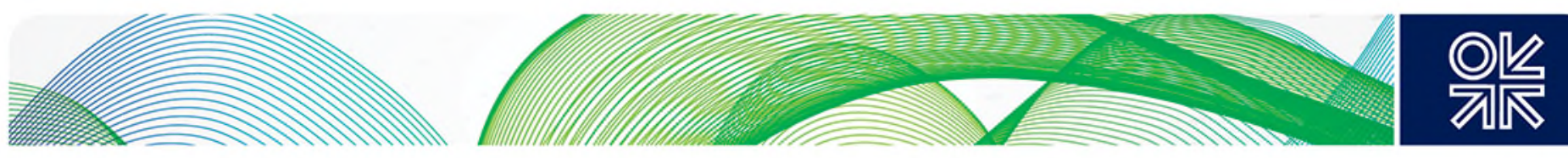

many MENA countries - such as Iran, Algeria, Kuwait and Saudi Arabia - have higher T\&D losses than the world average (of around 8 per cent).

Table 4.1: Grid Access for Renewables in Selected MENA Countries, 2015

\begin{tabular}{|c|c|c|c|c|c|c|}
\hline & & & & \multicolumn{3}{|c|}{$\begin{array}{l}\text { Technical Guidelines Adopted to } \\
\text { Connect: }\end{array}$} \\
\hline & $\begin{array}{l}\text { Guaranteed } \\
\text { grid access }\end{array}$ & $\begin{array}{l}\text { Priority } \\
\text { access }\end{array}$ & $\begin{array}{l}\text { Priority } \\
\text { dispatch }\end{array}$ & $\begin{array}{l}\text { Small } \\
\text { scale PV } \\
\text { systems } \\
\text { to low } \\
\text { voltage } \\
\text { grid }\end{array}$ & $\begin{array}{l}\text { Utility } \\
\text { scale PV } \\
\text { systems to } \\
\text { medium } \\
\text { and HV } \\
\text { grid }\end{array}$ & $\begin{array}{l}\text { Wind parks } \\
\text { to medium } \\
\text { and HV } \\
\text { grid }\end{array}$ \\
\hline $\begin{array}{l}\text { Saudi } \\
\text { Arabia }\end{array}$ & No & No & No & No & No & No \\
\hline Kuwait & No & No & No & No & No & No \\
\hline UAE & No & No & No & No & No & No \\
\hline Qatar & No & No & No & No & No & No \\
\hline Algeria & $\begin{array}{l}\text { Executive } \\
\text { decree 06- } \\
428(2006), \\
06-429 \\
\text { (2006), and } \\
\text { order of } 2008\end{array}$ & No & $\begin{array}{l}\text { Yes, once a } \\
\text { renewable } \\
\text { energy } \\
\text { system is } \\
\text { connected }\end{array}$ & No & $\begin{array}{l}\text { Under } \\
\text { preparation }\end{array}$ & $\begin{array}{l}\text { Under } \\
\text { preparation }\end{array}$ \\
\hline Oman & No & No & No & Yes & $\mathrm{n} / \mathrm{a}$ & $n / a$ \\
\hline Bahrain & No & No & No & No & No & No \\
\hline Jordan & $\begin{array}{l}\text { Non- } \\
\text { discriminatory } \\
\text { guaranteed } \\
\text { access } \\
\text { foreseen by } \\
\text { Law No. } 13 \\
\text { (2012) on } \\
\text { Renewable } \\
\text { Energy and } \\
\text { Energy } \\
\text { Efficiency, } \\
\text { Article 8C }\end{array}$ & No & No & Yes & Yes & Yes \\
\hline Iran* & Yes & $\mathrm{N} / \mathrm{A}$ & $\mathrm{N} / \mathrm{A}$ & Yes & Yes & Yes \\
\hline
\end{tabular}

Source: (RCREEE/AFEX, 2015) * SUNA (2013) 

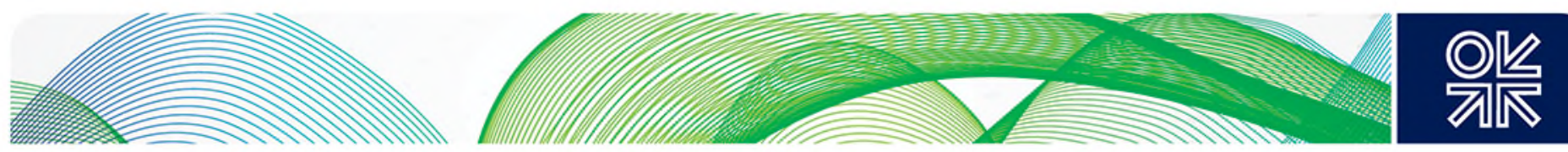

Figure 4.1: T\&D Losses in MENA Countries (\% of Output)

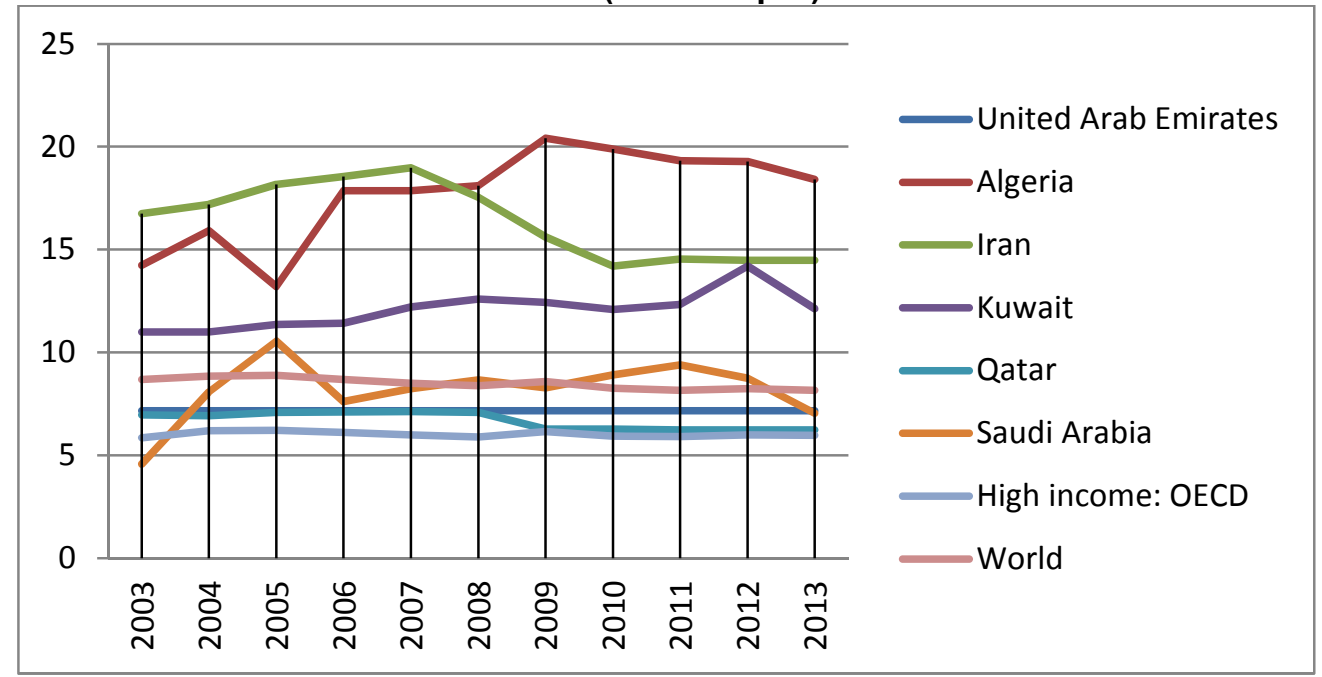

Source: WDI (2016)

In addition to domestic infrastructure, countries also need to increase their interconnections at the regional level to improve their balancing capability, flexibility and security of supply. The GCC interconnection (GCCl) grid links Saudi Arabia, Qatar, Bahrain, Kuwait, Oman and the UAE. More than 10 contracts worth more than 1 Bn US\$ were awarded in the first phase linking Saudi with Kuwait, Bahrain and Qatar. Another initiative, the Seven Countries Interconnection Project launched in the 1990s aims to interconnect the grids of Libya, Egypt, Jordan, Syria, Iraq, Turkey and Lebanon. Within the region, an HVDC (high-voltage, direct current) line is planned between Saudi and Egypt. However, electricity transfers among $\mathrm{GCCl}$ grid users have reportedly been small-scale and mainly during times of outages. ${ }^{34}$ An important reason for the lack of electricity trade among these countries is the prevailing view of the interconnector as a backup rather than an opportunity for optimisation of the electricity system. ${ }^{35}$ It is expected that the penetration of renewables would provide new opportunities for regional cooperation and electricity trade in this regard. However, major efforts are required towards building trust for this sort of cooperation, as well as adding the necessary infrastructure or reinforcing the existing grid where needed. ${ }^{36}$

\subsection{Institutional challenges}

The successful implementation of renewable policy depends on the existence of necessary institutional capacity, including administrative, economic and political. The exact type of institutions required depends on the specific policy and its complexity, as this indicates the degree to which a policy instrument is considered as legitimate, acceptable (commitment and long-term support from government and public) and can be adopted. At the same time, the enhancement of institutional capacity must not lead to excessive administrative and regulatory burdens as they themselves can become impediments to renewable deployment. For example, if obtaining all relevant permits for renewable technology becomes expensive and lengthy it increases transaction cost and discourages

\footnotetext{
${ }^{34}$ Oman's state electricity and water firm wants to prioritise the development of a spot market by 2019 , with trials of electricity trading through the $\mathrm{GCCl}$ grid in 2016.

${ }^{35}$ While the GCC interconnection facilitates the infrastructure for electricity trade and cooperation among the six countries, it has mainly been utilised for emergency transfers of electricity to meet peak loads or to shore up lost capacity from plant outages to help avert partial blackouts (KAPSARC, 2016).

${ }^{36}$ For instance, the Saudi electricity sector needs $\$ 133 \mathrm{Bn}$ of investments in generation, transmission and distribution (MEES, 2016h).
} 

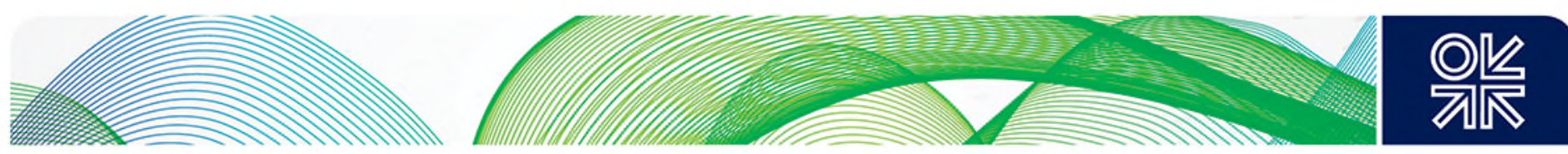

investors. Effective institutions need to reduce the administrative burden of procurement, selection of contract holders, granting contracts, site selection, construction and environmental permits and grid access to the minimum. While dedicated renewable energy agencies or departments are necessary to enable coordination amongst stakeholders, independent regulators are critical to ensuring transparency and engendering stability in the implementation of policies.

Studies suggest that the MENA countries' institutional feasibility should include the existence of renewable energy ministries and regulators, their resources, competencies, laws, existing strategies and activities in renewable energy (DIE, 2012). As table 3.3 shows for selected resource-rich (and nonresource-rich) MENA countries, most countries have a dedicated renewable policy agency. However, the current institutional frameworks for energy in the MENA countries are largely dominated by the oil and gas sector and renewables have yet to be integrated within these. Further, power companies are key enablers of renewables deployment; however, MENA countries' power sectors resemble variations of the single-buyer model, with large and powerful state-owned companies ${ }^{37}$ overseeing the generation, purchase and supply of power based on traditional business models which can be disrupted by renewables deployment. Renewable policy institutions on their own arguably do not yet have sufficient influence over these companies to the extent that renewables could be favoured within the energy mix. Further, despite relatively centralised systems (implying that renewables targets should be easily enforceable in theory), many MENA countries' institutional frameworks lack a strong state authority that can champion renewable energy whilst at the same time exerting overarching influence on existing powerful institutions such as the traditional state-owned utility companies to tilt the balance in favour of renewables.

Table 3.3: Institutions for Renewables Deployment

\begin{tabular}{|c|c|c|}
\hline & $\begin{array}{l}\text { Electricity regulatory } \\
\text { agency }\end{array}$ & RE Policy Maker (Dedicated Agency/Department) \\
\hline $\begin{array}{r}\text { Saudi } \\
\text { Arabia }\end{array}$ & $\begin{array}{l}\text { Electricity and Co-generation } \\
\text { Regulatory Authority (ECRA) }\end{array}$ & $\begin{array}{l}\text { King Abdullah City for Atomic and Renewable Energy } \\
\text { (KACARE) }\end{array}$ \\
\hline Iran & Ministry of Energy & $\begin{array}{l}\text { Renewable Energy Organisation of Iran (SUNA) in } \\
\text { collaboration with Ministry of Energy }\end{array}$ \\
\hline Kuwait & None & None \\
\hline UAE & $\begin{array}{l}\text { Abu Dhabi Regulation and } \\
\text { Supervision Bureau }\end{array}$ & $\begin{array}{l}\text { Clean Energy and Climate Change Department at } \\
\text { Ministry of Energy }\end{array}$ \\
\hline Algeria & $\begin{array}{l}\text { Commission de Régulation } \\
\text { de l'Electricité et du Gaz } \\
\text { (CREG) }\end{array}$ & $\begin{array}{l}\text { Renewable Energy and Energy Conservation } \\
\text { Directorate at the Ministry of Energy and Mines }\end{array}$ \\
\hline Qatar & None & $\begin{array}{l}\text { Qatar General Water and Electricity Corporation } \\
\text { (KAHRAMAA) }\end{array}$ \\
\hline Jordan & $\begin{array}{l}\text { Energy and Minerals } \\
\text { Regulatory Commission }\end{array}$ & $\begin{array}{l}\text { Renewable Energy Department at the Ministry of } \\
\text { Energy and Mineral Resources }\end{array}$ \\
\hline Morocco & None & $\begin{array}{l}\text { Energy and Renewable Energies at the Ministry of } \\
\text { Energy, Mines, Water and Environment; Agency for } \\
\text { the Development of Renewable Energy and Energy } \\
\text { Efficiency }\end{array}$ \\
\hline Egypt & $\begin{array}{l}\text { Egyptian Electric Utility and } \\
\text { Consumer Protection } \\
\text { Regulatory Agency }\end{array}$ & New and Renewable Energy Authority \\
\hline
\end{tabular}

Souce: RCREEE/AFEX (2015); Authors

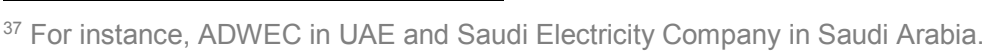



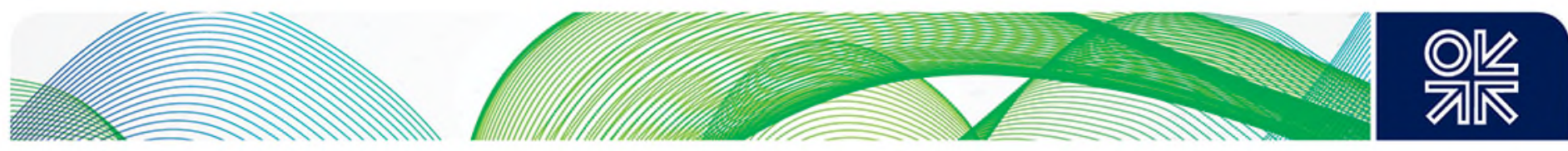

The lack of regulatory independence is also a major concern for renewables deployment in the region, as governments often overturn regulatory decisions and in many cases tariffs are set inflexibly. Although electricity reform legislation has been enacted in nearly all resource-rich MENA countries, the institutions to implement them are lagging behind. For instance, Saudi Arabia's 2005 reform legislation envisaged competitive market structures ${ }^{38}$, yet its regulator ECRA has no control over tariffs, and is thus unable to engender competitive forces and incentive regulation in the industry. Algeria's 2002 reform legislation provided for competitive wholesale market through the establishment of entities such as a market operator whose function is to determine the clearing price. However, this has been long delayed in practice. Technical and institutional challenges to renewables therefore include the building of the required trading, clearing and settlement regulations and systems to be operated by a future 'market maker', and the development of structures and resources capable of handling heightened system operation demands in electricity markets with intermittent renewables (Dyllick-Brenzinger and Finger, 2013). Issues such as regulatory instability, lack of comprehensive legislation, inadequate operational standards for power systems with intermittent renewables, along with incomplete regulatory frameworks for ancillary services, grid access, balancing rules and balancing responsibilities are among major barriers to renewables deployment in the MENA countries. Adding to this, the lack of transparency and predictability in support schemes for renewable deployment highlights the extent of institutional challenges.

\subsection{Risks and uncertainties}

The economic environment of industries always contains risks and uncertainty and renewable energy is not an exception to this. Renewable energy investors face a range of risks including political risk, policy and regulatory risks, technology risk, currency and liquidity risk and power off-taker risk (IRENA, 2016b). These risks and uncertainties not only affect the path of technological evolution and demand for renewable energy, but more importantly the cost of capital and ability to finance projects. Therefore, risk and uncertainties are serious barriers for scaling up renewable deployment and addressing them require access to effective risk mitigation instruments.

Political risks are related to the political events that have a negative impact on the value of investment including war, civil disturbance, sabotage, expropriation and non-honouring of contracts. Policy and regulatory risks are those risks that are related to changes in investment incentives (for example, removal of renewable subsidies), network codes, grid connection costs model, and permitting processes among others. In resource-rich MENA countries, renewable investors face uncertainty both where there is no specific renewable policy as well as after policy incentives are designed and implemented. The pre-implementation uncertainties are factors such as not knowing if, when, or what type of policy will be implemented to incentivise renewables. The post-implementation uncertainties are related to the stability, transparency, trust and insurance for long-term support. Developers also face technology risk which is related to nascent renewable technologies and inexperienced and unskilled workers operating the facilities. Some technologies may not have a proven track record of operation in the MENA region and this poses a risk to investors. Additionally, the local workforce may lack the skills needed to operate and maintain the power system with a lot of renewable technologies. This becomes more pronounced knowing that a segment of the skilled workers in these economies tend to be expatriates.

The currency risk pertains to the volatility of domestic currency value with respect to foreign currencies. This is particularly important as most renewable power producers' costs are in hard currency (e.g., dollar or euro because of loans), whereas their revenue is in local currency (e.g., feed in tariff paid in domestic currency). Local currency depreciation leads to a mismatch between cost and revenue and can negatively impact the financial health of renewable energy companies. In resource-rich countries

${ }^{38}$ Recent announcements indicate that the Saudi Electricity Company intends to unbundle by end-2016 (MEES, 2016h). 

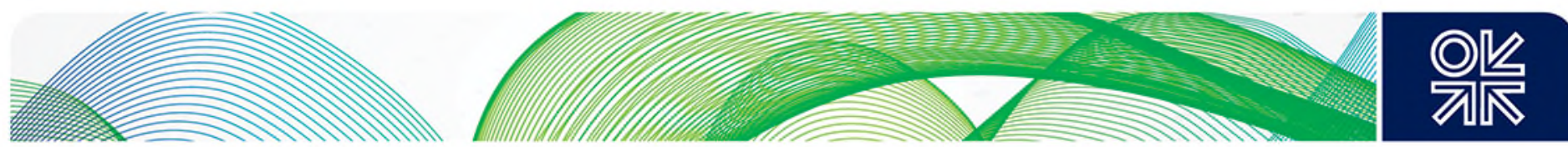

of the GCC, this is arguably less of a risk due to the currency pegs to the US dollar. However, in other countries such as Egypt - which offered higher feed-in-tariffs than many other countries in the region $(\$ 0.13 / \mathrm{kWh})$ meaning that investors were willing to take on currency risks, the imposition of capital controls in 2015 meant that investors could not repatriate their profits, which is a major disincentive to investment. Additionally, renewable energy companies are exposed to the risk of insufficient liquidity which happens if there is a mismatch between the time of revenue receipts and cost payments.

Finally, the credit and/or default risk of the power off-taker is an important concern for renewable energy developers. This is especially exacerbated when the market structure is such that there is only one offtaker (e.g., public utility company) and power producers have no choice but to contract with the single buyer and bear the credit risk. In India, one of the fastest-growing markets for solar power at present, some developers are hesitant to sign Power Purchase Agreements (PPAs) with state-owned distribution utilities due to their low credit ratings. ${ }^{39}$ Forty per cent of allocated projects have reportedly been delayed or cancelled over the last two years. ${ }^{40}$ These issues raise questions over the viability and compatibility of the existing market structure for managing the risks facing project developers. The evolution away from the current market models to structures that enable efficient development of renewables can eliminate counter-party risk. In some of the MENA countries (for example in the GCC), considerable fiscal buffers imply that the government can ultimately indemnify the single buyer (state power company) - however, the risk of monopolistic behaviour on the part of the state company still remains.

The premium on the cost of capital resulting from investors' perception of risk can prevent them from entering the renewable energy industry altogether. The effective financial de- risk instrument provided by public financial institutions along with appropriate government policies are crucial to mobilising private capital into the renewable industry. Some MENA countries have attempted to set up separate renewable energy funds to underwrite new projects - for instance, the UAE, Morocco and Jordan. Algeria's renewable fund is financed through 1 per cent of oil revenues allocated to it (RCREEE/AFEX, 2015). Such funds are under consideration in Saudi Arabia, Bahrain and Kuwait as well. However, given limited public finance, government guarantees are also an effective way of leveraging private capital. Guarantee instruments can cover many of the renewable energy investment risks and thus make them attractive to investors. Financial guarantees have long been used to back fossil fuel investment, but their use in the renewable energy industry remains limited because of financial institutions' lack of experience in the renewables industry as well as low demand for these instruments (IRENA, 2016b).

\footnotetext{
${ }^{39}$ Developers are subject to a penalty or bid bond if they fail to follow through on projects after winning the auction. Often, firms prefer to pay the penalty rather than entering into PPAs with state distribution utilities.

${ }^{40}$ See 'India's cutthroat solar auctions - behind the hype', PV Tech, 22 December 2015. http://www.pv-tech.org/features/indiascutthroat-solar-auctions-behind-the-hype
} 

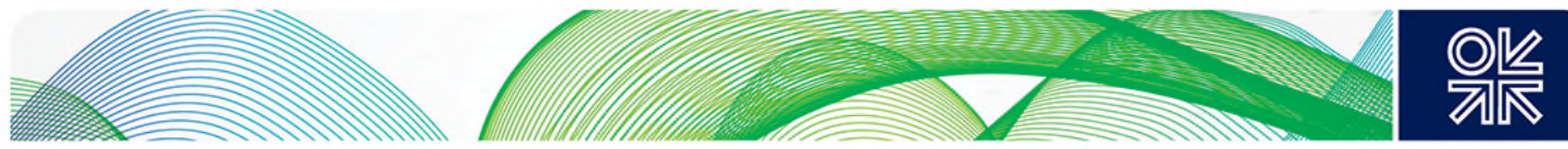

\section{Power sector reform and renewable deployment}

The structure of the power sector directly affects the deployment of renewables as it is the platform upon which incentive mechanisms for renewables should be designed. In countries with non-liberalised power sectors, electricity services are provided through a vertically integrated monopoly (VIM) which owns and operate all elements across the supply chain: generation, transmission, distribution and retail supply. The state-owned monopoly plans for investments (and operation) of all installed facilities. For instance, generation projects are evaluated and chosen upon the basis of which ones can be achieved at the lowest costs (using domestic fuels and enabling job creation), while providing an adequate level of reliability. The planning of grid expansion is done within a framework of integrated resource planning to minimize the costs of providing electricity while meeting certain reliability and security criteria.

Although most MENA countries had vertically-integrated electricity sectors until the late 1990s/early 2000 s, electricity reform legislation has led to the beginnings of a transition away from this model, but progress has been slow. The reform laws of Iran (1999), Saudi Arabia (2005) and Algeria (2002) envision wholesale markets; the UAE's (Abu Dhabi) reform law (1998) envisages disaggregated single buyers with bilateral trading and third party access, whereas the reform laws of Kuwait $(2008 ; 2010)$ and Qatar are limited to Independent Power Producers (IPPs) in generation, and unbundling (for Qatar) (Dyllick-Brenzinger and Finger, 2013).

Therefore, electricity markets in the region have different degrees of liberalisation, some of which are more suited to renewable deployment. In principle, based on the level of liberalisation, electricity market structures can be presented as five distinct models which range from a vertically integrated monopoly to a fully competitive wholesale and retail electricity market. Figure 5.1 presents these models and the associated set of feasible renewable policy instruments that can be implemented under each market structure. The first structure after a vertically integrated monopoly (VIM) is the single buyer model. At this stage, the monopoly over generation is formally lifted and IPPs are allowed to enter the market and generate electricity. Therefore, as opposed to VIM where incentives for renewables deployment can only be given to the monopoly, private investors are incentivised under the single buyer model. The presence of private investment under the single buyer model enables the usage of tendering in addition to other support schemes under VIM.

Figure 5.1: Models of electricity market structure and the range of feasible renewable support schemes at each stage

Models of market structure and the range of support schemes
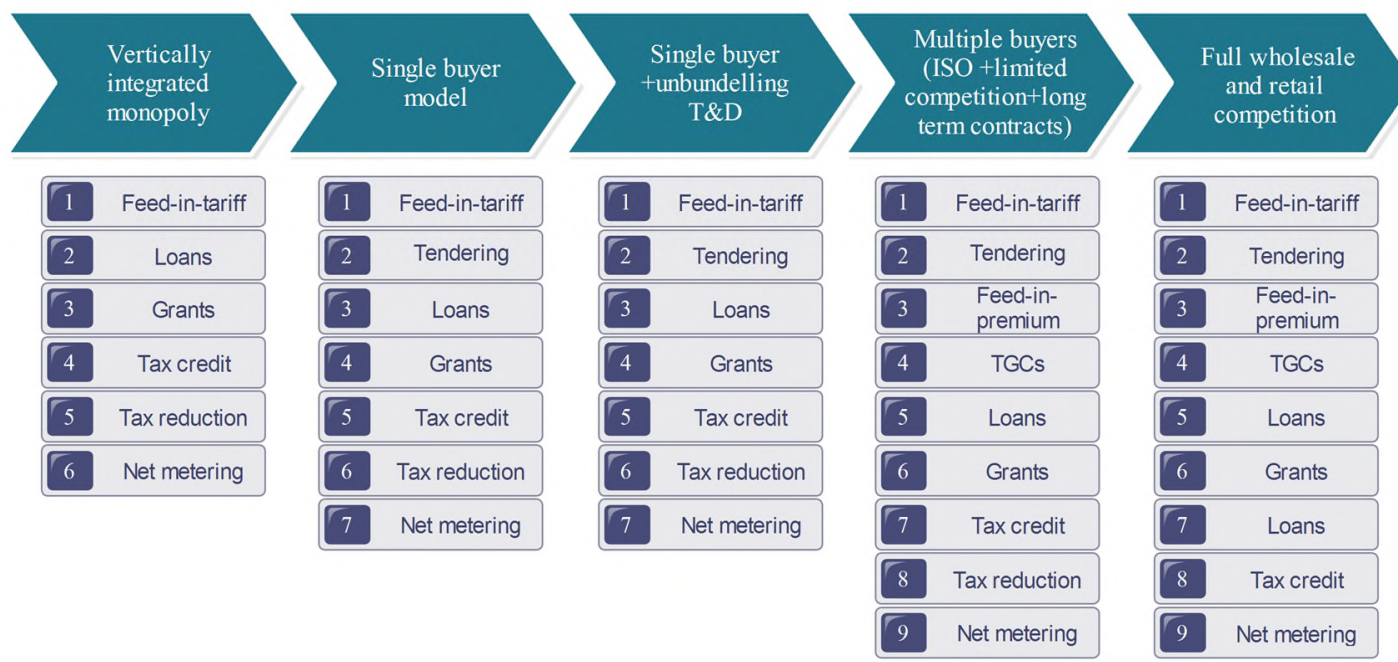

Source: Authors 

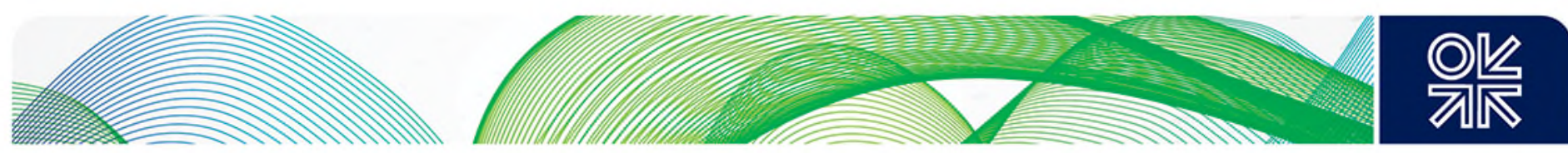

The challenge of a bundled single buyer is that the coexistence of a huge integrated monopoly (single buyer or public utility) along with several private generators may hamper renewable advancement. Firstly, from an investment perspective, penetration of renewables disrupts the business model of the incumbent monopoly. This is because the promotion of private renewable plants and on-site generation transfers assets away from the utility company to its consumers and private investors. Since utilities generate a return on the equity or assets they own, this is a direct threat to their earnings. Thus, provision of incentives to private investors and end-users for the installation of renewables tends to not be supported by vertically integrated single buyers. Secondly, from an operational standpoint, the vertically integrated single buyer may prioritise its own generation assets for dispatching when demand is weak. The inefficiency generated from this behaviour benefits the monopoly at the cost of smaller private generators and consumers.

Therefore, in order to avoid the abuse of monopoly power, countries need to gradually move to the third model, which is an unbundled single buyer. In this step, generation is unbundled from transmission and distribution (T\&D). The unbundling can initially be in the form of separating the monopoly's accounts, but should at some point transition to full unbundling, or separation of ownership. In this way, the single buyer would be the grid company which operates the transmission network (and also distribution network if it is not separated) and does not own any generation asset. The grid company is also subject to regulation for non-discriminatory grid access and cost efficiency improvement in order to alleviate monopoly power and remove perverse incentives.

Apart from the efficiency issues with a monopsonistic market structure, transactions with a single buyer always include credit and default risk on the part of the off-taker. The presence of multiple buyers in the market not only reduces this risk but can also improve efficiency. Therefore, a new market structure emerged in some countries where there is more than one off-taker of energy and the market is governed by limited competition and long-term contracts. The buyers can be regional transmission companies, suppliers of electricity to the end-users and/or large consumers of electricity. The operator of the grid can be an independent system operator (ISO) or the largest owner of the transmission network (if there are several transmission companies), in which case it is called the transmission system operator (TSO).

The fifth model includes fully competitive wholesale and retail electricity markets. The exact design of wholesale market varies in countries with liberalised power sectors, but it typically includes a day-ahead market, a market for bilateral contracts, and a balancing market. Countries can adopt new schemes such as feed-in-premiums and TGCs in addition to the instruments that can be used in a non-liberalised electricity market. An advantage of these new schemes is that the investor of a renewable facility needs to recover parts of its costs through the market, and part of it through direct subsidies. This spreads the cost between both the government budget and the consumer.

Figure 5.2 depicts power sector structures currently prevalent in MENA countries, which have two common characteristics: first, they are all variants of the single buyer model, with the government retaining a dominant role. And second, the models differ on the level at which competition between economic actors is brought to bear (Dyllick-Brenzinger and Finger, 2013). Most countries have opted for auction-based competition in the tendering process for IPPs (or Integrated Water and Power Producers - IWPPs) in generation (the only segment with private actors) based on long-term Power Purchase Agreements. Iran is the only country in the region where competition is introduced through bid-based auctions in the day-ahead and/or spot market for generation, with the purchase price of electricity for the single buyer in the pool determined by the interaction of competing generators. ${ }^{41}$

\footnotetext{
${ }^{41}$ The Iranian pool is said to resemble original electricity pool of England and Wales.
} 

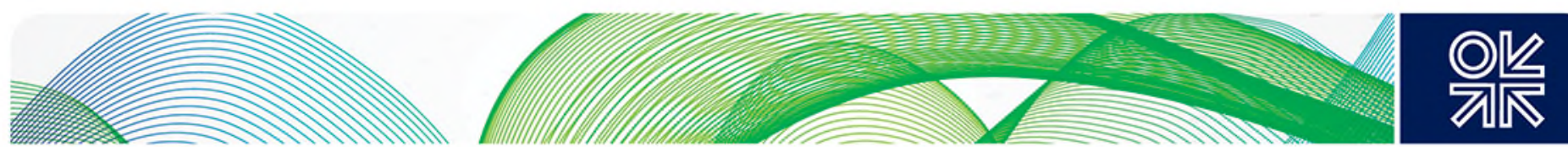

Figure 5.2: MENA Power Sector Models

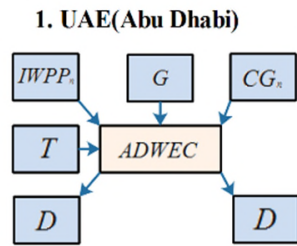

Single buyer+ unbundling T\&D

4. Saudi Arabia

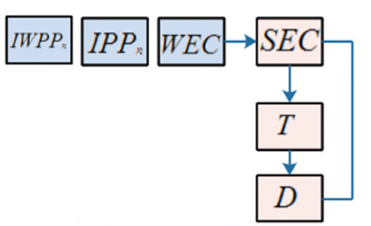

Single buycr+ unbundling $\mathrm{T}$

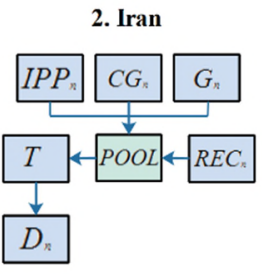

Limited wholesale market

5. Kuwait

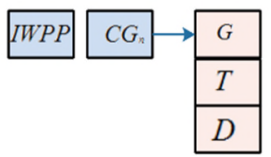

Single buyer

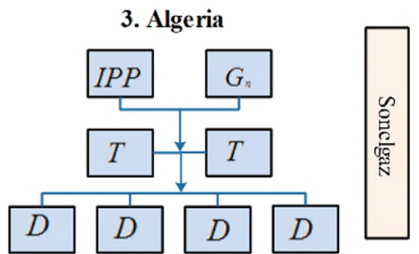

Single buyer+ unbundling T\&D

5. Qatar

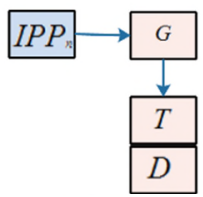

Single buyer

\begin{tabular}{|c|c|c|}
\hline IPP- Independent Power Producer & POOL-Iran mandatory power pool & WEC-Saudi Arabia Water\& electricity Co. \\
\hline CG-Captive Generator (auto producer) & az- Algeria's electricity holding company ( single buyer) & \\
\hline
\end{tabular}

Source: Authors

A challenge of having competitive wholesale markets where both renewable and traditional generation facilities operate simultaneously, is that it can lead to market breakdown and a distortion of electricity price signals, especially when renewables have out-of-market payments. This is because electricity prices in liberalized wholesale markets under the OECD model are set according to the system marginal cost, that is, the short-term marginal cost of the last (and, following the merit order, typically most expensive) plant that is required to be brought onto the system in order to meet demand (Keay et al, 2013; Sen, 2014). On the other hand, renewable energy generators have very high capital costs but almost zero marginal cost of operation and this can lead to a wholesale electricity price which does not perform its intended function - i.e., provide an incentive for investment and efficient operation. This is now a major challenge in developed economies. This also shows the importance of electricity market design, which needs to be fit for renewables.

The tension between liberalisation and decarbonisation in OECD countries has been caused partly due to the fact that renewables were imposed upon a market designed for conventional fossil fuel electricity. The MENA countries, by contrast, have the opportunity to design their electricity markets and sectors around the incorporation of renewables at the outset. This creates a "last mover advantage" for these countries and allows them to tap into years of experience gained through trial-and-error in advanced economies. These countries can adopt market structures that avoid both issues related to the perverse incentives of integrated monopolies and counter-part risk of single buyer and also the market breakdown under fully liberalised electricity systems. 

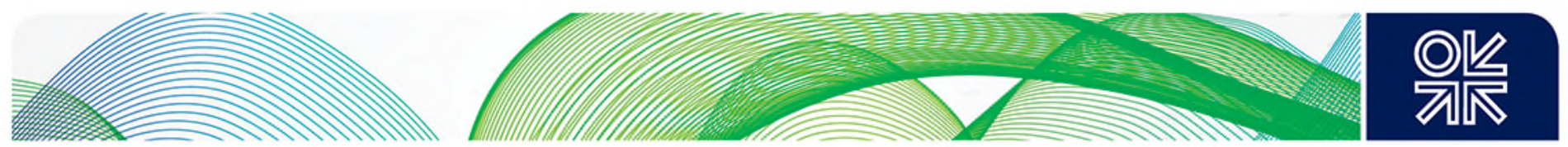

\section{Conclusions}

Despite the enormous renewable energy potential in resource-rich MENA countries, their share of renewables in electricity generation is among the lowest in the world, not only lagging behind similar high-income economies, but also low-income economies. Although in recent years most MENA countries have announced renewables targets, these have extremely ambitious timeframes and face significant challenges given current high levels of hydrocarbon resource-dependency. This paper asks how the efficient development of renewables in resource-rich MENA countries can best be incentivised (focusing primarily on Saudi Arabia, Iran, Kuwait, UAE, Algeria and Qatar). It also identifies the main barriers to renewable promotion in these countries.

The paper contends that while the main obstacles to the deployment of renewables are institutional challenges, grid inadequacy and risk and uncertainties, the solutions for spurring investment lie on a policy instrument spectrum in which a full market-based approach and a full renewable subsidies model (in addition to existing fossil fuel subsides) are two polar cases. The market approach requires the complete removal of fossil fuel subsidies, whereas a renewable subsidies programme requires longterm support and commitment on the part of government. Furthermore, the market approach promotes competition in the energy sector and relies entirely on price signals, whereas a fully subsidised renewable program encourages investment in renewables by offering various forms of direct and indirect financial incentives. Additionally, implementing the market-oriented approach is politically challenging while adopting a fully subsidised renewable programme is economically problematic given the current level of fossil fuel subsides in these countries and tight fiscal budgets in the aftermath of oil price fall.

Therefore, there is a trade-off between the two dimensions of the fiscal burden and political acceptance across the policy instrument spectrum which implies the two polar solutions themselves are not easily and fully implementable in these countries. We propose a combinatorial approach in which incentive for investment is provided partially through the market and partially through government subsidies. The combinatorial approach can be part of a dynamic process where governments start from the most feasible point on the proposed policy instrument spectrum and gradually move towards market based incentive provision over the medium to long term where all forms of energy subsidies are eventually phased out. The dynamic combinatorial approach not only reduces fiscal pressure on government budgets (compared to a fully subsidised model), but also averts political risks by allowing businesses and households to slowly adapt to the new environment, where energy carriers are priced at their full economic costs.

Although the provision of investment incentives is necessary for renewable deployment, such incentives are not sufficient on their own, as barriers to deployment also need to be removed. Resource-rich countries need to ensure that the necessary institutional capacity exists in the country to deliver renewables, generators have access to a reliable and flexible grid and also appropriate risk mitigation instruments are available to deal with inherent risks and uncertainties. These barriers can cause underinvestment not just in renewables but also in conventional generation which is essential to backup renewables. The paper asserts that most MENA economies are lagging behind in energy sector reform and market liberalisation, and while they have moved away from vertically integrated structures, most retain variants of the single-buyer model which in some cases is accompanied by the unbundling of generation and network segments. In order to avoid the perverse incentives seen in integrated monopolies and reduce the credit and default risk posed by having just a single power off taker, an appropriate market structure needs to be developed. The fact that resource-rich MENA countries have not emulated the experiences of other OECD and non-OECD countries implies that they have some sort of last-mover advantage, in the sense that they can tap into years of international (e.g. European) experience to avoid design mistakes and create a sustainable solution compatible with their own context. 

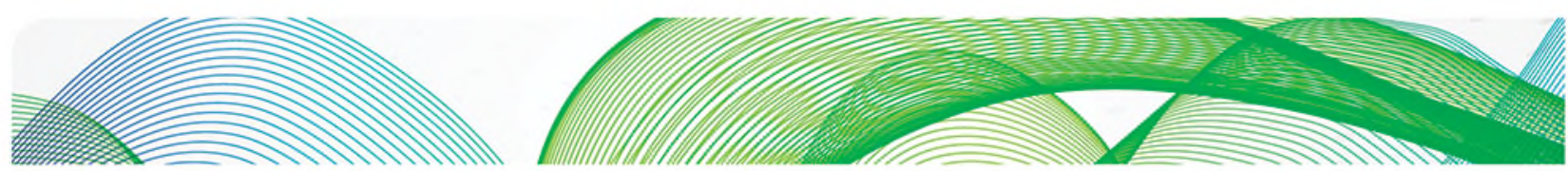

\section{References}

AOGD (2015) Lebanon Electricity, Arab Oil and Gas Directory, 2015.

Buchan, D. and Keay, M. (2014) 'The EU's new energy and climate goals for 2030: under-ambitious and over-bearing?' Oxford Energy Comment, Oxford Institute for Energy Studies

https://www.oxfordenergy.org/wpcms/wp-content/uploads/2014/01/The-EUs-new-energy-and-climategoals-for-2030.pdf

Bridle, R., L. Kiston and P. Wooders (2014). Fossil-Fuel Subsidies: A barrier to renewable energy in five Middle East and North African countries.

https://www.iisd.org/gsi/sites/default/files/fossil-fuel-subsidies-renewable-energy-middle-east-northafrican-countri\%20\%20\%20.pdf

Carafa, L., Frisari, G. and Vidican, G. (2015) 'Electricity transition in the Middle East and North Africa: a de-risking governance approach', Journal of Cleaner Production, 1-14

Dyllick-Brenzinger, R.M. and Finger, M. (2013) 'Review of electricity sector reform in five large, oil and gas exporting MENA countries: Current status and outlook', Energy Strategy Reviews, 2, 31-45.

DIE (2012) "Building Domestic Capabilities in Renewable Energy: A case study of Egypt " German Development Institute (DIE), https://www.die-gdi.de/uploads/media/Studies_66.pdf.

EIA (2016). How much coal, natural gas, or petroleum is used to generate a kilowatthour of electricity? https://www.eia.gov/tools/faqs/faq.cfm?id=667\&t=6 [last retrieved 09/06/2016].

EIA (2016) Share of Renewables in Net Generation

ENI (2015) Oil and Gas Year

Fattouh, B. Sen, A. and Moerenhout, T. (2016) 'Striking the Right Balance? GCC Energy Price Reforms in a Low Price Environment', Oxford Energy Comment, Oxford Institute for Energy Studies. https://www.oxfordenergy.org/wpcms/wp-content/uploads/2016/04/Striking-the-Right-Balance-GCCEnergy-Pricing-Reforms-in-a-Low-Price-Environment.pdf

Fattouh, B. and Sen, A. (2015) 'Saudi Arabia Oil Policy: More than Meets the Eye?' MEP13, Oxford Institute for Energy Studies. https://www.oxfordenergy.org/wpcms/wp-content/uploads/2015/06/MEP13.pdf

IEA (2015) Renewables in the MENA Region, December 2015, International Energy Agency http://www.iea.org/media/workshops/2015/cop21/otherevents/5DecPhilibert.pdf [Accessed 20 June]

IEA (2016) IEA Joint Policies and Measures Database, International Energy Agency, http://www.iea.org/policiesandmeasures/renewableenergy/ [Accessed 20 June]

IISD (2014), "Fossil-Fuel Subsidies: A barrier to renewable energy in five Middle East and North African countries", The International Institute for Sustainable Development.

https://www.iisd.org/gsi/sites/default/files/fossil-fuel-subsidies-renewable-energy-middle-east-northafrican-countri\%20\%20\%20.pdf.

IMF (2016) IMF Data Mapper. http://www.imf.org/external/datamapper/index.php?db=FM [Accessed 14 June]

IRENA (2016) Renewable Energy Market Analysis - The GCC Region, International Renewable Energy Agency, Abu Dhabi.

http://www.irena.org/DocumentDownloads/Publications/IRENA Market GCC 2016.pdf. 

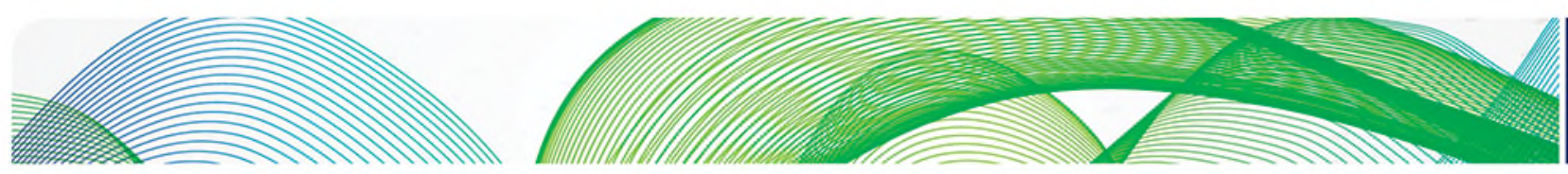

IRENA (2016b), 'Unlocking Renewable Energy Investment: The Role of Risk Mitigation and Structured Finance,' IRENA, Abu Dhabi.

http://www.irena.org/DocumentDownloads/Publications/IRENA_Risk_Mitigation_and_Structured_Fina nce_2016.pdf.

IRENA Global Atlas for Renewable Energy (2016) http://irena.masdar.ac.ae/

IRENA (2013) MENA Renewables Status Report, International Renewable Energy Agency.

KAPSARC (2016) Opportunities and Challenges in Reforming Energy Prices in Gulf Cooperation Council Countries, King Abdullah Petroleum Studies and Research Centre, June 2016/ KS-1629WB028A.

Keay, M., Rhys, J., and Robinson, D. (2013b). 'Decarbonization of the electricity industry - is there still a place for markets?', OIES Working Paper EL9, Oxford Institute for Energy Studies, November.

Lilliestam, J. and Patt, A. (2015) 'Barriers, Risks and Policies for Renewables in the Gulf States', Energies, 8, 8263-85.

Luomi, M. (2015) 'Post-2015 presents green growth opportunities for Gulf oil exporters, Oxford Energy Forum 102, Oxford Institute for Energy Studies.

MEES (2016a) 'Saudi Edges up Capacity, Looks to IPPs for Boost', MEES, 59 (20), 20 May.

MEES (2016b) 'UAE Tendering 115GW of Solar, Dubai Receives Record Low Bid', MEES, 59 (18), 6 May.

MEES (2016c) 'Saudis Slash Subsidies as Oil Revenue Collapses', MEES, 59 (1), 8 January.

MEES (2016d) 'Kuwait's Budget Deficit Set to Soar as Spending Continues Despite Subsidy Cuts', MEES, 59 (5), 5 February.

MEES (2016e) 'Saudi Arabia and Qatar Rethink Fuel Subsidies, Kuwait Still Undecided', MEES, 59 (19), 13 May.

MEES (2016f) 'Iran Approves Higher Budget Spending in 2016-17', MEES, 59 (18), 6 May.

MEES (2016g) 'King Salman fires Saudi Electricity \& Minister After Price Hike Complaints', MEES, 59 (17), 29 April.

MEES (2016h) 'Saudi to Split State Power Giant 'By End 2016”, MEES, 59 (9), 4 March.

MEES (2015) 'MENA Power Survey: Generators Seek Fuel Diversity; Capacity up 3.4\% to 370GW', MEES, 58 (1), 2 January.

Mittal, S. (2016) '\$500 Million Renewable Energy Joint Venture Planned in Qatar', Cleantechnica, 1 January. http://cleantechnica.com/2016/01/01/500-million-renewable-energy-ioint-venture-plannedgatar/ [Accessed 20 June]

MOEM (2016) 'Electricité de Gaz', Ministry of Energy, Algeria http://www.energy.gov.dz/francais/index.php?page=electricite [Accessed 20 june]

MoE (2015), "Electricity tariffs and laws and regulations of its sale", Iran's Ministry of Energy, available online at: http://tariff.moe.gov.ir [in Farsi] \{accessed 21 June 2016\}.

Nakhle, C. (2015) 'Middle East Oil and Gas Producers are Facing a New Price Reality', Carnegie Endowment for International Peace, 30 June. http://carnegieendowment.org/2015/06/30/middle-eastand-north-africa-oil-producers-are-facing-new-price-reality/ied3 

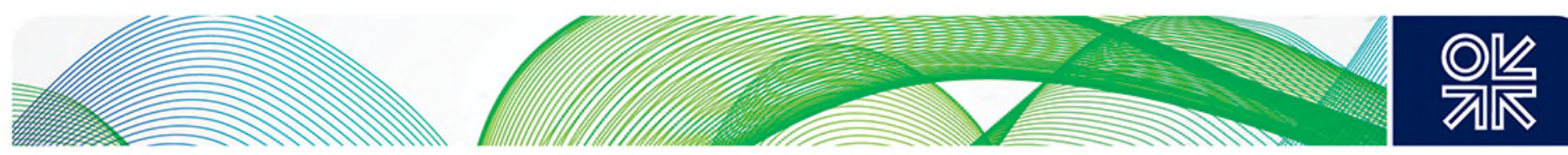

NBAD (2015) 'Financing the Future of Energy - The Opportunities for the Gulf's Financial Services Sector', National Bank of Abu Dhabi, University of Cambridge, and PwC.

https://www.pwc.com/m1/en/publications/documents/financing-the-future-of-energy-executivesummary-english.pdf

Sen, A. (2014) 'Divergent Paths to a Common Goal: An Overview of Challenges to Electricity Sector Reform in Developing versus Developed Countries' OIES Paper EL10, Oxford Institute for Energy Studies.

Siddiqi, A. and Anadon, L.D. (2011) 'The Water-Energy Nexus in Middle East and North Africa', Energy Policy, 39 (6), pp. 4529-40.

SHANA (2015)' Director of Renewable Energy Organisation of Iran: Iran's energy basket is to be diversified". Petro Energy Information Network (SHANA) [in Farsi] http://www.shana.ir/fa/newsagency/230704 [accessed 30 June 2016]

Sdralevich, C., R. Sab, Y. Zouhar and G. Albertin (2014) Subsidy Reform in the Middle East and North Africa Recent Progress and Challenges Ahead, Middle East and Central Asia Department (Washington, D.C.: International Monetary Fund).

SUNA (2013) "The guideline for construction of non-governmental renewable energy power plants". Renewable Energy Organisation of Iran (SUNA). (In Farsi)

http://www.suna.org.ir/suna_content/media/image/2013/11/2729_orig.pdf?t=635214082155373750.

RCREEE/AFEX (2015) Arab Future Energy Index, Regional Centre for Renewable Energy and Energy Efficiency, Egypt.

UNEP (2016) Global Trends in Renewable Energy Investment 2016, United Nations Environment Programme. http://fs-unepcentre.org/sites/default/files/publications/globaltrendsinrenewableenergyinvestment2016lowres_0.pdf WDI (2016) World Bank World Development Indicators. http://data.worldbank.org/data-catalog/worlddevelopment-indicators [Accessed 12 June]

World Bank (2016) Country and Lending Groups. http://data.worldbank.org/about/country-andlending-groups [Accessed 12 June]

Zahno, M. and Castro, P. (2016) 'Fossil Fuel Subsidies as a Barrier to Renewable Energy Deployment: Evidence from a Global Sample Analysis', Department of Political Science UZH; Centre for Comparative and International Studies. 